\title{
Cem anos de Código Civil Alemão: 0 BGB de 1896 e o Código Civil Brasileiro de $1916^{1}$
}

\author{
Claudia Lima ellaxques
}

Professora Adjunta da Universidade Federal do Rio Grande do Sul, Doutora em Direito pela Universidade de Heidelberg, Mestre em Direito em Direito Civil e Direito Internacional Privado pela Universidade de Tübingen, Alemanha.

\section{Introdução}

bjetivo deste trabalho, mais do que prestar uma homenagem ao centenário da basilar codificação alemã, é analisar a influência do Código Civil alemão de 1896 (BGB) sobre o Código Civil Brasileiro de 1916. No Direito Comparado, os autores alemães classificam o Direito brasileiro, normalmente, como pertencen te à chamada família romana de direitos. Neste grupo de ordens jurídicas, o grande modelo legislativo, a grande influência em matéria de codificações, foi o Code Civil francês de $1804 .{ }^{3}$ Mesmo assim, parece ser pacífico na doutrina brasileira e alemã que o Código Civil Brasileiro (CCBr.), ao lado das influências do Code Civil , também sofreu influências das Codificações portuguesa, espanhola e italiana, assim como dos Códigos alemão e suíço. ${ }^{4}$ Igualmente a forte influência da doutrina jurídica alemã do século XIX sobre os projetos de Código e o

1. Versăo parcial e adaptada em português da Conferência apresentada em alemão no "IV Deutsch-Lusitanische Rechtstage: Hundert Jahre BGB", em 28 de novembro de 1996, na Universidade de Heidelberg, Alemanha. Nossas homenagens às bibliotecárias da Faculdade de Direito da UFRGS pelos seus esforços em preservar o abundante material do século XIX ainda existente em nossa Universidade.

2. Zweigert/Kötz, Einführung in die Rechtsvergleichung auf dem Gebiete des Privatrechts, 3. Auff., Tübingen, 1996,pg. 114 ( 8 V)). Veja também Betti, Emilio, Système du Code Civil Alemand, Milan, 1965, pg.7. Contrariamente, prefere René David a idéia de uma familia romano-germânica (famille de droit romano-germanique), veja David, René, Les grands systémes de droit contemporains, Paris, 1988, pg. 33ss.(Nr. 25 e 67).

3. Assim Zweigert/Kötz, pg. $74(\$ 6 \mathrm{I})$ e Betti, pg. 7.

4. Pontes de Miranda, Francisco, Fontes e Evoluçăo do Direito Civil Brasileiro, Rio de Janeiro, 1981, pg. 93, Couto e Silva, Clovis V. de, O Direito Civil Brasileiro em Perspectiva Histórica e Visão de Futuro, in: Revista de Informação Legislativa (Brasilia), Nr. 97 (11988), pg. 163, Zweigert/Kötz, pg. 114 (\$ 8 VI) e Ennecerus, Ludwig e Nipperdey, Hans Carl, Derecho Civil- Parte General, vol. 1, Tradução espanhola de Blas Pérez González, Barcelona, 1953, pg. 87 (\$12 Vili). 
próprio Código Civil Brasileiro de 1916, assim como o germanismo da Escola de Recife, são fatos históricos que não podem ser negados. ${ }^{5}$

Sendo assim, cabe aqui analisar e discutir duas teses sobre a possível influência do BGB sobre o vigente Código Civil brasileiro. Em primeiro lugar, com base na análise das diversas fontes de inspiração legislativa do CCBr., poderemos verificar se ambos os Códigos, alemão e brasileiro, apesar da diferença de 20 anos da data de suas aprovações possuem caracteríristicas comuns e devem ser considerados como "produtos" ou criações típicas do século XIX. ${ }^{6}$ Sendo assim, a relação entre os dois Códigos estaria marcada pelo momento histórico do liberalismo e de desenvolvimento da ciência do Direito no qual foram preparados: O Código Civil brasileiro foi elaborado, em verdade, de 1860 a $1899^{7}$ e o BGB alemão, por sua vez, de 1874 a $1896 .^{8} \mathrm{O}$ momento histórico e político semelhante os teria marcado de forma definitiva. O BGB encontra sua base científica na Pandectística alemã (pandektistischen Zivilrechtswissenschaft) do século XIX; o

CCBr., por sua vez, sofre múltiplas influências, mas mantém certa dose de originalidade criativa. Ambos os Códigos, ao fim, são criticados como codificações conservadoras, individualistas, científicas em excesso e não suficientemente sociais, a fechar as portas do século XIX, sem abrir as do século XX. ${ }^{9}$ A análise da influência da Es. cola Pandectística alemã sobre o Código Civil Brasileiro de 1916 pode explicar algumas destas coincidências, se bem que não todas, e merece, portanto, um estudo mais detalhado. Este estudo será aqui apresentado através da análise da vida e obra dos grandes juristas brasileiros daquela época, de seus respectivos projetos e trabalhos para a elaboração do Código Civil, visando identificar justamente a influência germânica nestes juristas brasileiros (Parte I).

A segunda tese a ser examinada é encontrada na própria doutrina alemã atual e na doutrina comparatista internacional e diz respeito diretamente a força (maior ou menor) da influência alemã no CCBr. Segundo opinião majoritária na doutrina comparatista, ${ }^{10}$ a influência alemã no Código Civil brasileiro estaria restrita ao siste-

\section{Betti, pg. 7 .}

6. Veja críticas de Radbruch e Zitelman ao BGB in: Zweigert/Kötz, pg. 142 ( $\$ 11$ l) e críticas ao Código Civil Brasileiro, in: Pontes de Miranda, Fontes, pg. 85: "A data mental do Código (como do BGB e do suiço) é bem 1899; não seria errôneo dizê-lo o antepenúltimo Código do século passado."

7. Pontes de Miranda, Fontes, pg. 85 e Couto e Silva, pg. 170.

8. Eisenhardt, Ulrich, Deutsche Rechtsgeschichte, 2. Aufl., München, 1995, pg. 381ss. (Nr. 575ss.); Kroeschell, Karl, Rechtsgeschichte Deutschlands im 20. Jahrhundert, Göttingen, 1992, pg. 11ss.; Schlosser, Hans, Grundzüge der Neueren Privatrechtsgeschichte, 7. Aufl, Heidelberg, 1993, pg. $152(\$ 5)$.

9. Veja as críticas de Otto von Gierke in: Płeiffer-Munz, Susanne, Soziales Recht ist deutsches Recht, Zürich, 1979, pg. 1ss.; compare também sobre o caráter conservador e continuista do BGB, Zweigert/Kótz, pg. 142 (\$11 I) e 147 (§ 11 III). Veja as críticas de Pontes de Miranda ao CCBr., in: Pontes de Miranda, Francisco, Brasil-Codigo Civil, Die Zivilgesetze der Gegenwart, criticas de Pontes de Miranda ao CCBr., in: Pontes de Miranda,
Bd. III, Heinsheimer, Karl, (Coord.), Mannheim, 1928, pg. XXII.

10. Zweiger/Kötz, pg. 114 (\$8 VI) e David, pg. 95 (Nr. 67). Ao contrário, observa cauteloso David, nota 1, pg. 95 (Nr. 67 ): "Lidée d'une 'partie générale' a été présentée sous forme législative pour la première fois au Brésil dans la Consolidaçăo das leis civis d'Augusto Teixeira de Freitas en 1858. Le Code civil brésilien de 1916 l'a consacrée en raison peut-être de ce précédent, plus que

Revista da Faculdade de Direito da UFRGS, v. 13, 1997 par imitation du BGB." ma adotado, influência esta sistemática, mas não tanto de conteúdo. O sistema escolhi do pelo legislador brasileiro, com uma parte geral e uma parte especial teria, então, sua origem na ciência jurídica alemã da época. ${ }^{11}$ É necessário, portanto, analisar em vamente, qual foi a influência alemã na dis tribuição sistemática das matérias no Código Civil brasileiro e, a contrário, qual a influência de conteúdo que o BGB de 1896 pode realmente exercer na elaboração da Codificação brasileira (Parte II).

\section{I- Elaboração do Código Civil \\ Brasileiro de 1916 e a \\ influência alemã}

A influência que os Projetos para o Código Civil alemão e o próprio $\mathrm{BGB}$, assim como a influência da doutrina científica alemã do século XIX sobre os vários vem ser aqui analisadas. Para tanto interessa não somente resgatar os caminhos da elaboração do Código Civil Brasileiro de 1916 (B), como também identificar as diferentes fontes estrangeiras, doutrinárias e legislativas, que a doutrina brasileira considera existir no projeto vitorioso de Clóvis Bevilaqua de 1899/1916 (A, 1).

Parece-nos, porém, que a melhor maneira de demonstrar esta possível influuma segunda parte, ainda que não exaustiprojetos de um Código Civil Brasileiro de- ência alemã em nossa legislação do início deste século não é a simples citação das possíveis fontes de inspiração, normas ou doutrinas estrangeiras que foram incorporadas ou adaptadas em nosso CCBr.. E sim, identificar e analisar a influência exercida pela doutrina e pela nascente legislação alemã nos grandes juristas brasileiros da época, artesões que - em tempo de escassa literatura e informação nas Faculdades pátrais - elaboraram ou trabalharam em projetos do qual resultou o CCBr. de 1916 $(\mathrm{A}, 2)$.

\section{A) Fontes históricas de inspiração e modelos estrangeiros do Código Civil Brasileiro}

\section{As diferentes fontes do Direito Civil Brasileiro}

O direito civil brasileiro só pode ser compreendido na sua formação dogmática e inspiração científica quando se tem presente as quatro fontes principais da ordem jurídica brasileira, que formaram suas características e seu espírito atual fontes é a portuguesa, através da "Verpflanzung12", isto é, a incorporação, o aporte, enxerto ou recepção forçada, do
A primeira e mais importante desta

11. Na versão original, em alemão, deste artigo, inclui-se estudo sobre a infiluência alemã na Lei de Introdução ao Código Civil brasileiro (letra C). Sobre o tema veja Pontes de Miranda, Fontes, pg. 99ss.

12. Rheinstein, Max, Einführung in die Rechtsvergleichung, München, 1987, pg. 125 (\$16): "De der Rezeption im eigentlichen Sinne sollte man den Vorgang der Verpflanzung eines Rechstphänomens unterscheiden. De Verpflanzung kann man sprechen, wenn eine Gruppe von Auswanderer ihr heimatliches Recht in eine neue Umwelt mitnimmt." 
direito português no Brasil durante o tempo colonial. ${ }^{13}$

O direito português trouxe consigo o direito romano incorporado, isto é, o jus commune europeu, ${ }^{14}$ do Corpus Juris Civilis trabalhado pelos Glossadores e Pós glossadores. ${ }^{15} \mathrm{O}$ direito português trouxe consigo, igualmente, uma forte influência do direito canônico da época ${ }^{16}$ e uma redu zida influência do direito germânico, no que se refere à autonomia de vontade do indivíduo e a alguns princípios morais. ${ }^{17}$

$\mathrm{Na}$ opinião de jushistoriadores bra sileiros e portugueses encontra-se o Códi go Civil Brasileiro de 1916 mais próximo de sua origem portuguesa que o próprio Código Civil Português de $1867 .{ }^{18} \mathrm{O}$ direito civil português vigorou no Brasil do des cobrimento até 1917 , e terá decisiva influência na tendência de nossa ordem jurídica de Continuidade, Formalismo ${ }^{19}$ e Unidade. ${ }^{20}$

Como segunda influência a ser citada, cabe lembrar o constante e normal con-

13. Pontes de Miranda, Fontes., pg. 27. O Autor utiliza expressão semelhante à "Verpflanzung", afirmando: "O Direito, no Brasil, não pode ser estudado desde as sementes; nasceu do galho da planta, que o colonizador português, - gente de rija têmpera, no ativo século XVI e naquele cansado século XVII em se completa o descobrimento da América, - trouxe e enxertou no novo continente."

14. Wieacker, Franz, História do Direito Moderno, [tradução Botelho Hespanha], Lisboa, 1980, pg. 129ss.

15. Moreira Alves, José Carlos, A Contribuiçăo do Antigo Direito Português no Código Civil Brasileiro, in: Estudos de Direito Civil Brasileiro e Português, Caetano, Marcello et allii, São Paulo, 1980, pg. 30.

16. Segundo Pontes de Miranda, Brasil- Codigo Civil, pg. XXXIII o direito canônico é até a República de 1889 uma das mais importantes fontes do direito brasileiro.

17. Pontes de Miranda, Fontes, pg. 27 e 28.

18. Moreira Alves, pg. 29f. $O$ autor cita estudos do historiador português Guilherme Braga da Cruz.

19. Veja, muito crítico, Steiner, Henry, The Legal System and Modernization in Brazil, in: Merryman, John Henry (Coord.), Comparative Law: Western European and Latin american Legal Systemn - Case and Materials, Charlottesville, Virginia, 1978, pg. 378ss.

20. Couto e Silva, Clóvis V. de, O Direito Civil Brasileiro em Perspectiva Histórica e Visão de Futuro, in: Revista de Informação Legislativa (Brasilia), N. 97 (I-1988), pg. 167

21. Almeida Costa, Mário J. de, Fundamentos Históricos do Direito Brasileiro in: Estudos de Direito Civil Brasileiro e Português, São Paulo, 1980, pg. 115.

22. Pontes de Miranda, Fontes, pg. 73 .

Revista da Faculdade de Direito da UFRGS, v. 13, 1997 cia brasileira baseou-se em muito nas Glosas de Accursius e Bartolus, a ponto de ser criticada. ${ }^{23}$ Pode-se afirmar, portanto, que, desde a portuguesa Lei da Boa Razão de 1769 , o direito comparado ${ }^{24}$ foi um tradicional meio de interpretação e atualização de nossas normas, visando a evolução (Rechtsfortbildung) do direito pátrio.

A Lei da Boa Razão introduz como importante Princípio de Interpretação e de Integração das já superadas normas das Ordenações e do direito romano comum a "recta ratio", que se encontraria na interpretação atual e na doutrina das nações cristãs civilizadas. ${ }^{25} \mathrm{~A}$ observação da communis opinio doctorum deveria, segundo a legislação do Marquês de Pombal, continuar, mas em forma reduzida. ${ }^{26}$ Note-se, porém, que devido as dificuldades da utilização da regra ou teste da Boa Razão, a citada Lei de 28 de agosto de 1772 ("Estatutos da Universidade de Coimbra”) previu uma direta

remissão ao direito estrangeiro atual à época ao prever a observação do chamado "usus modermus pandectarum", 27 que nada mais era do que a visão atualizada, já dogmática e científica do direito europeu comum.

Por outro lado, é necessário mencionar que no Brasil, até 1828 , não havia nenhuma Faculdade de Direito em funcionamento. ${ }^{28}$ Somente após a Independência de Portugal, em 7 de setembro de 1822 , pode se desenvolver uma escola jurídica verdadeiramente brasileira. $O$ primeiro Imperador do Brasil, Dom Pedro I, fundou as primeiras Faculdades de Direito (de Olinda e São Paulo) em solo brasileiro através da Lei de 11 de agosto de $1827 .{ }^{29} \mathrm{~A}$ utilização de um método comparatista para a interpretação, desenvolvimento e adaptação das vigentes normas portuguesas no Brasil conseguiu, na maioria das vezes, sucesso e estabeleceu-se como prática comum em nosso país. ${ }^{30}$

23. Pontes de Miranda, Brasil - Codigo Civil, pg. XXXII

24. Sobre a importância do direito comparado por força da Lei de 1772 escreve David, Note 2, pg. 48 (Nr. 34): "Les status nouveuax, donnés par le Marquis de Pombal à l'Université de Coimbra en 1772, prescrivent que l'enseignement soit donné desormais non plus sur la base du droit romain, mais sur une base de droit comparé, en considérant les principes de droit reconnus par les nations civilisées."

25. Veja Almeida Costa, pg. 115 e também Pontes de Miranda, Fontes, pg. 72.

26. Veja David, pg. 63 (Nr. 44): "la lei da boa razão affranchit les juges de l'obligation stricte de suivre les opinions d'Accurse et de Bartole et la communis opinio doctorum selon les règles qui avaient été prescrites par les Ordonnaces philippines."

27. Pontes de Miranda, Fontes, pg. 73: "Por ser árduo o critério da boa razäo, aconselhou-se 'como caminho mais plano e curto' (Estatutos, Livro II, Título V, Cap. $3, \S 6^{\circ}$ ), qual o de se ver o que o direito romano adotaram as naçōes cultas (\$ $7^{\circ}$ ): "Indagarão o uso moderno das mesmas leis romanas entre as sobreditas naçōes, que hoje habitam a Europa. E descobrindo que elas as observam e guardam ainda no tempo presente, terão as mesmas leis por aplicáveis, e daqui inferirão que elas têm oposição com algumas das referidas Leis e Direitos (Direito Natural, Direito das Gentes, Direito Político, Direito Mercantil, etc.), com que devem ser confrontadas: pois não é verossímil que, se entre elas houvesse repugnância, pela qual se devam haver abolidas, continuassen ainda hoje a observá-las, e guardá-las, tantas e tão sábias naçōes."

28. Sobre a importância dos juristas na recepção de um direito, veja a obra de Papachristos, A. C., La Réception des Droits Privé Etrangers comme Phénomène de Sociologie Juridique, Paris, 1975, pg. 43ss.

29. Piletti, Claudino e Piletti, Nelson, Filosofia e História da Educação, São Paulo, 1993, pg. 180.

30. Pereira, Caio Mário da Silva, A Ciência do Direito Comparado, in: Revista de Direito Comparado Luso-Brasileiro, N. 7, 1985, pg. 40.

Revista da Faculdade de Direito da UFRGS, v. 13, 1997 UFRGS

FACULDADE LE DIREITC

BIBLIOTECA 
Esta simpatia e fácil aceitação de idéias e doutrinas jurídicas estrangeiras deve se, em nossa opinião, em grande parte, a um nem sempre confessado idealismo jusnaturalista de nossos juristas. A idéia de um direito universal, verdadeira fonte da justiça nas nações civilizadas, pode ser encontrada na maioria dos legisladores e doutrinadores brasileiros. ${ }^{31}$

A terceira fonte deve ser procurada na tradição, ainda encontrada na Colônia, de valorizar os costumes, e possibilitar uma voluntária vinculação do juiz à jurisprudência pacificada ou costumeira dos Tribunais superiores, seja a prática da "Casa de Suplicação" portuguesa de elaborar Assen tos", seja a prática brasileira de elaborar "Súmulas" da jurisprudência assentada. ${ }^{32}$ Esta tendência não deve ser desprezada, pois, em um país de dimensões continen tais, permitiu uma razoável harmonia das decisões jurisprudênciais (Entscheidungsharmonie). ${ }^{33}$

O papel decisivo do direito dos juízes (Richterrecht) na evolução e desenvolvimento do direito brasileiro fica claro quando se observa que, até 1917 , as fontes legislativas

do direito civil eram muito lacunosas e esparsas. ${ }^{34} \mathrm{O}$ juiz português ou brasileiro utilizava , direta ou indiretamente (através das Glosas) o direito romano, como fonte subsidiária oficial para suprir as lacunas das Ordenações Manuelinas (de 1521) e das Ordenações Filipinas (de 1603)..$^{35}$ Formase aqui, portanto, uma característica do jurista brasileiro : uma predileção especial por Opiniões e Argumentos de Autoridade pela jurisprudência sumulada ou pacificada, como forma de orientar-se no caos - por abundância ou vácuo - legislativo. ${ }^{36}$

A quarta influência tem origem no momento político brasileiro, quando da formação de nossa atual legislação de direito civil, e pode ser divida em duas importantes fontes jus-políticas. Em primeiro lugar note-se que os primeiros projetos para o $\mathrm{CCBr}$. foram elaborados no tempo entre a Independência do Brasil (1822) e a República (1889). O Brasil era, portanto, um Império e pôde, assim, resistir relativamente bem à grande influência do revolucionário e republicano Code Civil francês de 1804. As fortes críticas de Teixeira de Freitas ${ }^{37}$ ao modelo do Code Civil não tinham, prova

31. Veja Galves, Carlos, O Direito Natural, in: Rev. Fac. de Direito de Passo Fundo, 1986, pg. $43 s s . ~ o$ qual cita Clóvis Bevilaqua Pontes de Miranda, Vicente Ráo e Miguel Reale; veja também Diniz, Maria Helena, As Lacunas no direito, São Paulo, 1981, pg. 184ss.

32. Pontes de Miranda, Fontes, pg. 67ss.

33. Assim Pontes de Miranda, Fontes, pg. 69

34. Assim Pontes de Miranda, Brasil- Codigo Civil, pg. XXXIII.

35. Moreira Alves, pg. 32 e 33. Veja também Moreira Alves, José Carlos, O Direito Romano e sua Influência no Direito BrasilieroRoteiro de Exposição, in: Roma-Brasilia I - Storia e Instituzioni, Associazione di Studi Sociali Latino-Americani (Coord.), Rom 1984, pg. 26-32.

36. Assim também Caenegem, R.C., An Historical introduction to private law, Cambridge, 1992, pg. 74

37. Veja as críticas de Freitas in: Freitas, Augusto Teixeira de, Código Civil - Esboço, Serviço de Documentaçáo do Ministério da Justiça e Negócios Interiores, 4. Bd., Rio de Janeiro, 1952, pg. LII e LIV: "Não obstante seu methodo artificial, e com o máo principio da transferencia do dominio só por effeito dos contractos, o Codigo Civil da França tem exercido poderosa influencia."

Revista da Faculdade de Direito da UFRGS, v. 13, 1997 velmente, só fonte científica, mas também, de certa maneira, origem política. Já o último e aceito Projeto do CCBr., que data de 1899, foi elaborado no tempo da República e sob a égide de uma ordem constitucional nova, federalista e não mais monárquica. Neste momento, a Codificação francesa ganha em importância e pode influenciar - como efetivamente aconteceu - fortemente o Código Civil Brasileiro. $\mathrm{O}$ Code Civil é das legislações estrangeiras aquela que maior número de normas do CCBr. consegue influenciar: 172 normas do CCBr. encontrariam nele sua inspiração. ${ }^{38}$

Note-se ainda que a primeira Constituição Republicana do Brasil de 1891 tem forte inspiração norte-americana, uma vez que com a ajuda de Rui Barbosa muitas instituições e normas daquela Constituição Federativa, - Presidential e Republicana serão incorporadas. ${ }^{39} \mathrm{O}$ Direito Constitucional brasileiro forma-se, assim, sob influência e com grande proximidade do modelo norte-americano. ${ }^{40}$ A mistura e o convívio destas duas famílias jurídicas, a família romana ou romano-germânica e a família da Common Law , através da Constituição norte-americana, explicam a tendência brasileira de um certo ecletismo jurídico, ${ }^{41}$ ain-

da mais hoje em que a força normativa da Constituição e a forte influência do direito público no direito privado não pode ser mais desconhecida.

As Codificações do século XIX e XX no Brasil e a crescente legislação esparsa estabelecem uma forte tendência positivista no país. Estas diferentes e mesmo contrárias influências, assim como o especial desenvolvimento social brasileiro, em um tipo de feudalismo colonial contraposto por uma grande imigração, acabaram formando o direito bràsileiro. Segundo muitos, o trabalho e convívio com as diferentes e contrárias fontes asseguraram a ele, justamente, certa originalidade. ${ }^{42}$

\section{A influência da ciência jurídica alemã sobre os mais importantes juristas brasileiros e sobre seus Projetos de Código Civil Brasileiro}

A influência da ciência jurídica alemã do século XIX sobre quatro juristas brasileiros da época, oriundos ou não da tradição culturalista da Escola de Recife, será aqui analisada, uma vez que os quatro juristas escolhidos (Teixeira de Freitas,

38. Pontes de Miranda, Fontes, pg. 93

39. Dolinger, Jacob, The influence of American Constitutional Law on the Brazilian Legal System, in: The American Journal of Comparative Law, Vol. 38, pg. 804

40. Assim Comparato, Fábio Konder, The Economic Order in the Brazilian Constitution of 1988, in: The American Journal of Comparative Law, Vol. 38, pg. 756f. e auch Dolinger, pg. 823ss.

41. Veja sobre a "Circulation de modèles extra-romanistes dans les pays romanistes", Sacco, Rodolfo, La comparaison juridique au senvice de la connaissance du droit, Paris, 1991, pg. 159ss.

42. Assim David, René, Le Droit Comparé - Droits d'Hier, Droits de Demain, Paris, 1982, pg. 162ss. e Couto e Silva, pg. 163. Já Catalano e Valladão (Le droit latino-américain,Paris, 1954) defendem a idéia de uma família jurídica latino-americana; veja Catalano, Pierangelo, Sistema Juridico Latino-Americano, in: Enciclopédia Saraiva, São Paulo, 1982, Bd. 69, pg. 256 e também Catalano, Pierangelo, Direito Romano atual, Sistemas Jurídicos e Direito Latino-Americano, in: Revista de Direito Civil (São Paulo), vol. 44, pg. 14ss.

Revista da Faculdade de Direito da UFRGS, v. 13, 1997 
Tobias Barreto, Clóvis Bevilaqua e Rui Barbosa) encontram-se, na opinião da maioria, entre os mais importantes da história do direito no Brasil e tiveram papel decisivo na elaboração e crítica dos Projetos de Código Civil Brasileiro. ${ }^{43}$

\section{a) A influência alemã em Teixeira de Freitas}

Teixeira de Freitas é tido como o maior romanista e jurista codificador do Império. ${ }^{44}$ Nascido na Bahia em 1816, Freitas estudou até 1837 na Faculdade de Direito de Olinda e fundou em 1843, com apenas 27 anos de idade, o Institutos dos Advogados do Brasil. ${ }^{45} \mathrm{Em} 1857$ elaborou para o Império a primeira reunião sistemática e exaustiva das leis civis Brasil independente, a chamada "Consolidação das Leis Civis". A Consolidação teve como base as vigentes "Ordenações Filipinas" de 1602 e alcançou até 1917 - isto é, mais do que meio século - a autoridade de um verdadeiro Código Civil Brasileiro. ${ }^{46}$ de uma Introdução sistemática de 100 pá-
A Consolidação veio acompanhada

ginas elaborada pelo próprio Teixeira de Freitas. ${ }^{47}$ Nesta Introdução esclarece Freitas porque ele recusa tanto o modelo romano das Institutas de Caius, ${ }^{48}$ quanto o modelo e a sistemática francesa presente no Code Civil ${ }^{49}$ : Sua consolidação será organizada em uma Parte Geral e uma Parte Especial !

Freitas retira a idéia de uma Parte Geral do direito romano: "Omne jus vel ad personas pertinet, vel ad res, vel ad actiones" (Dig. L. 1 de stat hom., Inst. L. 1.T. 3.princ, Inst. Gaio Comment. 1. N. 8). ${ }^{50}$ Apesar de Freitas utilizar em sua Introdução da Consolidação prioritariamente autores franceses e textos romanos, não deixa de analisar , no que concerne a divisão das matérias do direito civil, a opinião Savigny e Leibnitz. Analisa, em especial, a opinião da Escola Histórica contra a divisão utilizada nas Institutas e afirma: "Mais tarde a necessidade de uma melhor classificação foi geralmente sentida, innumeros ensaios succedêrão-se, rapidamente, o methodo antigo foi quasi banido das escolas. Fallamos da Alemanha, o paiz da mediação, onde a Sciencia do Direito, associando-se á historia, é á philologia, tem alcança-

43. Veja Paul, Stolleis, pg. 85. O autor cita a obra monografica de Valmireh Chacon, Da Escola de Recife ao Código Civil de 1969.

44. Pontes de Miranda, Fontes, pg. 80. Veja sobre a vida e a obra de Augusto Teixeira de Freitas, Wolf Paul, in dem biographischen Lexikon: Stolleis, Michael (Coord.) Juristen, München, 1995, pg. 608.

45. Carneiro, Levi, Estudo Crítico-Biográfico, in: Código Civil - Esboço, Serviço de Documentação do Ministério da Justiça e Negócios Interiores, 4. Bd., Rio de Janeiro, 1952, pg. VIII.

46. Assim Wolf, Paul, in: Stolleis, pg. 608.

47. Veja Freitas, Augusto Teixeira de, Consolidação das Leis civil - Publicação Autorizada pelo Governo, 3. Aufl., Rio de Janeiro, 1896, pg. XIX a CCXX.

48. Freitas, Introdução à Consolidação das Leis civis - Publicaçáo Autorizada pelo Governo, 3. Aufl., Rio de Janeiro, 1896, pg. XL e XLI: "Nas Institutas, destinadas ao ensino, a pretendida normas devêra ter sido rigorosamente observada. tambem isto não se confirma....Esta incoherente distribuiçăo de materias..."

49. Freitas, Introdução, pg. LII e LIV: "Com muita razão se tem dito que a ultima divisão do Codigo Civil Francez poderia ter comprehendido todas as leis civis, e que o tratado das pessoas e das cousas não passa de simples preliminar...Não obstante seu methodo artificial... o Codigo Civil da França tem exercido poderosa influencia."

50. Freitas, introdução, pg. XL.

Revista da Faculdade de Direito da UFRGS, v. 13, 1997 do os mais brilhantes triumphos. Não são em tudo concordes os Jurisconsultos da nova escola, mas pronuncião-se com poucas excepções contra a inintelligivel divisão de - pessoas, cousas e ações-." ${ }^{11}$ A referida Consolidação traz uma Parte Geral, divida em dois tópicos: Das Pessoas e Das Cousas. ${ }^{52}$

A grande obra, porém, de Teixeira de Freitas foi o "Código Civil- Esboço" de 1960, o inacabado projeto de Código Civil para o Brasil com seus 4.908 Artigos, geralmente chamado de "Esboço". ${ }^{53}$ Segundo Clóvis Bevilaqua o "Esboço" é a contribuição mais original e valiosa para o direito brasileiro. ${ }^{54}$

No "Esboço" desenvolve Freitas ainda mais sua Teoria da divisão sistemática das matérias: a Parte Geral tratará também dos Fatos jurídicos! Esta inclusão deve-se, segundo opinião corrente, à crescente influência dos estudos de Savigny sobre Teixeira de Freitas. ${ }^{55}$ A divisão elaborada por Freitas é, segundo a doutrina brasileira, original e própria e não a divisão "objetiva" proposta por Savigny. ${ }^{56}$ A divisão do Esboço em Parte Geral e Parte Especial e sua sub-divisão em Direito das Pessoas e das Coisas significava uma alternativa - à época- ao modelo preponderante do Code $\mathrm{C}$ -

51. Freitas, Introdução, pg. LIl, veja citaçōes de Savigny, pg. XLI, L, Leibnitz, pg. XLIX,L e LI. Analisada foi também o Código Civil austríaco, a ABGB, idem, pg. LVI. Segundo o professor catedrático de Coimbra Orlando de Carvalho, (Carvalho, Orlando de, Teixeira de Freitas e a Unificação do Direito Privado, in: Revista de Direito da Faculdade de Coimbra, vol. LX (1984), pg. 1-86) Teixeira de Freitas filiou-se ao sistema das Pandectas, em interpretação da Parte Geral que remonta a obra de Hugo (1789) e Heise (1807), após incorporada por Savigny, negando qualquer originalidade a Freitas, Carvalho, pg. 36 e nota 55. Carvalho analisa, porém, o Esboço de 1860 e não especialmente a Consolidação, que the é anterior.

52. Freitas, Introdução, pg. CXII e CXIII: "Sob as idéias fundamentaes, que temos desenvolvido, a CONSOLIDAÇÃO DAS LEIS CIVIS apresetna em sua primeira divisão duas grandes categorias, que fớrmão sua Parte Especial. Á esta Parte Especial antecede uma Parte Geral, que the serve de prolegomenos. A Parte Geral trata em dois Titulos das pessoas e das cousas, que são os elementos constitutivos de todas as relaçōes juridicas, e portanto, das relaçōes juridicas na esphera do Direito Civil."

53. O Esboço foi publicado, de forma incompleta, pela primeira vez em 1860 e até 1865 pela Typographia Universal Laemmert do Rio de Janeiro, e e em 1952, novamente publicado pelo Ministério da Justiça: Freitas, Augusto Teixeira de, Código Civil - Esboço, Serviço de Documentação do Ministério da Justiça e Negócios Interiores, 4. Bd., Rio de Janeiro, 1952. Na edição de 1952 receberá o "Esboço" uma informativa introduçăo elaborada por Levi Carneiro. Carneiro esclarece que Freitas elaborou 5.016 artigos mas que somente 4908 destes form publicados oficialmente pelo governo. O Capitulo III (Disposicóes communs aos direitos, Civil - Esboço, Serviço de Documentaçāo do Ministério da Justiça e Negócios Interiores, 4. Bd., Rio de Janeiro, 1952, pg. Xll.

54. Bevilaqua, Clóvis, Em Defesa do Projeto do Código Civil, Rio de Janeiro, 1906, pg. 23: "Mas si o Esboço não poude ser transformado em lei, entrou para o acervo da jurisprudencia patria como a sua producção mais valiosa, pela riqueza, segurança $e$ originalidade das idéias."

55. Bevilaqua, Clóvis, Linhas e perfis jurídicos, Rio de Janeiro, 1930, pg. 121ss. e Carneiro, pg. XX. Carvalho, pg. 36, afirma que Freitas "confessa na carta de $1867^{\prime \prime}$ a influência sofrida pelo sistema das pandectas, na interpretação de alemã, em especial da obra de Savigny.

56. Bevilaqua, Clóvis, Linhas e perfis jurídicos, Rio de Janeiro, 1930, pg. 121 e 123: "A classificaçăo adoptada por Teixeira de Freitas é uma feliz novidade, com que se enriqueceu a technica juridica. Mais tarde, o auctor a melhoraria e completaria. Mas, já entấo, é brilhante feito de uma inteligencia organica. Não é a mais a distribuição tripartida de Gaio... Também não é, ainda, a classificação objectiva de Savigny, que o jurisconsulto brasiliero jamais aceitou em seu conjunto. É uma forma intermedia de pensamento, que, seguindo a visăo, obscura ainda, da jurisprudencia romana, e assilando os resultados das investigaçóes allemãs, possue individuação, e merece que a assignalemos, com estima, na historia das idéias juridicas." Assim também Carneiro, pg. XX e XXV|; Pontes de Miranda, Fontes, pg. 98. Contra, Couto e Silva, pg. 168, o qual identifica na divisão da Parte Geral do "Esboço" uma forte e decisiva influência da obra de Savigny sobre Teixeira de Freitas. 
vil francês e teria sido o motivo - aliado à precisão dos conceitos e da linguagem jurídica utilizada por Freitas - do grande suces so do "Esboço" como modelo legislativo, especialmente na Argentina. ${ }^{57}$

Freitas decidiu-se, por outro lado, pela Unificação das normas de Direito $\mathrm{Ci}$ vil e Direito Comercial. Apesar do Código Comercial Brasileiro datar de 1850, Freitas considerava em 1860 esta unificação necessária . Neste sentido, a Parte Geral do Esboço deveria ser considerada um Código Geral, contendo as normas básicas para as relações privadas, normas de direito privado geral. A Parte Especial por sua vez, seria o Código Civil, que regularia o direito civil e comercial, afirmando: .... "não há mesmo alguma razão de ser para tal seleção de leis.". 50

Neste Código único de direito privado dois diferentes capítulos regulariam o direito civil e o direito comercial, enquanto um terceiro capítulo trataria dos contratos comuns aos dois. ${ }^{59}$ Parece ter sido este o verdadeiro motivo da recusa pelo governo do Império do Esboço como Projeto de Código Civil e não simplesmente o atraso na entrega da versão completa. ${ }^{60}$ A crítica mais comum ao Esboço ataca sua extensão, com 4.908 Artigos e a cientificidade excessiva de seu "Código Geral", verdadeira Parte Geral do Direito Privado.

\section{b) A Influência alemã na Faculdade de Direito de Recife - Tobias Barreto, Clóvis \\ Bevilaqua e Rui Barbosa}

Segundo Losano, foi mérito de Tobias Barreto de Meneses (1839-1889) ter divulgado e recepcionado a cultura e a ciência jurídica alemã na chamada Escola de Recife ou "Escola Alemã do Recife". ${ }^{61}$ Nascido em Sergipe,em 1839, apartir de 1863 estudou Barreto na Faculdade de Direito de Recife e fundou o chamado "culturalismo jurídico" "62, um chamado à renovação e desenvolvimento cultural no Brasil, com vistas a uma cultura jurídica humanista ${ }^{63} \mathrm{e}$, indiretamente, ao fim do Império. ${ }^{64}$

57. Pontes de Miranda, Fontes, pg. 98 e Carneiro, pg. XVIII. Carneiro destaca a influência do Esboço nos Códigos da época na Argentina, Uruguai e Paraguai, veja Carneiro, pg. XXXIII.

58. Carneiro, pg. XXI cita Freitas: "O 'Código Civil' conteria, sob essa mesma denominação, 'o direito civil e o comercial'.... 'não há mesmo alguma razấo de ser para tal seleção de leis."

59. Carneiro, pg. XXIV

60. Assim também Carvalho, pg. 38ss.

61. Losano, Mario G. Die deutsche Bibliothek Tobias Barreto in Recife, in: Mitteilungen der Deutsch-Brasilianischen Juristenvereinigung, 1/92, pg. 2. Do mesmo autor, La scuola di recife e l'Influenza tedesca sul diritto brasiliano, in: Tarello, G. (Coord.), Materiale per 1/92, pg. 2. Do mesmo autor, La scuola di recife e l'Influenza
una storia della Cultura Giuridica, 4, 1974, pg. 323-415.

62. Chacon, Valmireh, Tobias Barreto e Dom Pedro II: Duas faces do Germanismo Brasiliero, in: Obras completas de Tobias Barreto, Ministério da Cultura (Coord.), Introduçăo por Valmireh Chacon, Brasilia, 1990, pg.14s. Veja Barreto, Tobias, Estudos de Direito e Política, Ministério da Educação e Cultura, Rio de Janeiro, 1962, pg. 33: "Dizer que o direito é um produto da cultura humana importa negar que êle seja, como ensinava a finada escola racionalista e ainda hoje sustentam os seus póstumos sectários, uma entidade metafisica, anterior e superior ao homen..."

63. Paul, in: Stolleis, pg. 66 .

64. Dom Pedro ll era de família germânica, neto do Imperador da Áustria e primo do imperador alemão, mesmo assim Barreto ficará famoso por suas críticas à Dom Pedro II. Barreto mantinha um germanismo "seletivo" e será o primeiro a citar no Brasil os

Revista da Faculdade de Direito da UFRGS, v. 13, 1997
Trata-se do maior autor, filósofo do direito e penalista de seu tempo, que em muito influenciou os intelectuais e juristas brasileiros, acostumados a uma orientação até então quase que exclusivamente francesa. ${ }^{65}$ Barreto é considerado o fundador da Escola de Recife e com seu marcante "germanismo" trouxe aos juristas brasileiros o contato com a ciência, filosofia e literatura alemã da época e especialmente com a obra do então praticamente desconhecido no Brasil, Rudolph von Jhering. ${ }^{66}$

Professor de Filosofia do Direito da Faculdade de Recife apartir de 1883, Barreto publicou dois livros escritos por ele Revista com o significativo título: "Deutscher Kämpfer: Literarisches und politisches Zeitungsblatt für die Ausbreitung des Deutschtums in Norden Brasiliens" (Lutadores Alemães: Revista literária e política para a Expansão do Germanismo no Norte do Brasil) ${ }^{67}$, o qual a partir de 1880 terá sua versão também em português, intitulada: "Estudos Alemães: Revista Mensal de Philosophia, Direito, Literatura e Crítica. ${ }^{68}$ próprio em alemão e, em 1875, um Jornal/

Mulato originário da família de um escrivão, Barreto mostra sua genialidade ao aprender como auto-didata e com parca bibliografia disponível Latim, Alemão e Russo. ${ }^{69}$ Em virtude de sua luta pelo fim da escravidão e do Império foi Barreto perseguido, perdendo sua cátedra e morrendo pobre no mesmo ano em que o Brasil tornava-se uma República. ${ }^{70}$

A tradição culturalista da Escola de Recife vai ser continuada, por Clóvis Bevilaqua. ${ }^{71}$ Clóvis Bevilaqua, nascido em 1859, estudou na Escola de Barreto e mais tarde tornou-se Professor da Cadeira de "Legislação Comparada" na Faculdade de Direito de Recife. ${ }^{72}$ Bevilaqua é o autor do projeto aprovado de Código Civil Brasileiro, datado de $1899 .{ }^{73}$ Os precisos e científicos Cometários ao $\mathrm{CCBr}$., assim como os manuais de Direito Civil elaborados por Bevilaqua são considerados obras fundamentais para a ciência jurídica brasileira. Em seu Cometário apresenta Bevilaqua a doutrina civilista atual com forte aproximação à doutrina pandectística, aliada a uma gran-

tabal oriundo de uma familia de "novos cristäos" e mulato que lutou pelo fim da escravidão e do Império. Veja detalhes de suas opiniöes politicas in: Chacon, pg. 14ss.

65. Couto e Silva, Clóvis, Saudação de Abertura do Congresso Jurídico Brasil-Alemanha, in: Couto e Silva, Clóvis (Coord.), Studien zum Brasileiron e Deutschen Recht, Faculdade de Direito/UFRGS, Porto Alegre, 1985, pg. 9.

66. Losano, pg. 2 e Paul, in: Stolleis, pg. 66

67. Tradução nossa, segundo o significado. Note-se a relação entre o título do Jornal e a célebre obra de Jhering de 1872 "Kampt ums Recht'(Luta pelo Direito).

68. Veja Losano, pg. 2 e Paul,in: Stolleis, pg. 66.

69. Veja Paul, Stolleis, pg. 65.

70. Chacon, pg. 15 e Paul, in: Stolleis, pg. 66.

71. Couto e Silva, pg. 169

72. Pontes de Miranda, Brasil-Codigo Civil, pg. XXVIII e Paul, in: Stolleis, pg. 85.

73. Couto e Silva, pg. 169 
de influência da visão positivista de Auguste Comte. ${ }^{74}$

Outro grande jurista brasileiro é também originário da Escola de Recife: Rui Barbosa. Nascido em 1849, Barbosa estudou Direito em Recife e São Paulo e tornou-se mais tarde Constitucionalista e Consultor Jurídico da República, elaborador da primeira Constituição republicana do Brasil em $1891 .{ }^{75}$ Nesta Constituição é dominante a influência da Constituição norte-americana. Político e Senador desempenhará Rui Barbosa importante papel na aprovação e crítica do Anteprojeto de $\mathrm{CCBr}$. Em virtude de suas críticas à linguagem e à forma do Projeto de $\mathrm{CCBr}$. de Bevilaqua, o Senado aprovará mais de 186 Sugestões de melhoramento e modificações ao Projeto, em um processo de discussão, em várias comissóes, que durará mais do que 12 anos. ${ }^{76}$ Somente em 26 de dezembro de 1915 é o Projeto Bevilaqua aprovado. Promulgado em $1^{0}$ de janeiro de 1916 entrará em vigor em $1^{0}$ de janeiro de $1917 .{ }^{77}$

\section{B) Momento Histórico da elaboração do Código Civil}

\section{Brasileiro de 1916 e suas Fontes principais}

Mesmo se o Código Civil Brasileiro (CCBr.) foi aprovado somente no ínicio do século XX (1916), é necessário observar que a elaboração deste márco codificador para a história do direito civil brasileiro começou muito antes, com a Independência de Portugal em 1822. Segundo Lei de 20 de outubro de 1823 continuaram vigorando no Império as Ordenações Filipinas, Leis e Decretos promulgados pelos reis de Portugal até 25 de abril de 1821, enquanto se não organizasse um novo Código ou não fossem aqueles alterados. ${ }^{78} \mathrm{Da}$ mesma forma previu o Art. 179 XVIII da Constituição imperial do Brasil de 1824, que: “ Organizar-se-á, quanto antes, um Código Civil e um Criminal, fundado nas sólidas sos Projetos serão elaborados até que os trabalhos mais importantes e pioneiros como o de Teixeira de Freitas em 1860 seja preparado. ${ }^{80}$ O Projeto enfim aprovado só o será o de 1899, da lavra de Clóvis Bevilaqua ${ }^{81}$ Dos quase 16 anos de sua discussão parlamentar vão resultar em mudanbases da Justiça e da Eqüidade." ${ }^{\prime 79}$ Numero-

74. Assim tb. Paul, in: Stolleis, pg. 86, Couto e Silva, pg. 169s. e implicitamente, Pontes de Miranda, Fontes, pg. 441. Como legislação básica ao Art. 1 do CCBr. traz Bevilaqua as seguintes fontes: Art. 1 AGBGB-Código Austríaco, Art. 1 CCColombiano e Art. 3 CCPortuguês. A seguinte bibliografia: 0 brasileiro Espínola e 0 alemã Endemann. Em seus Comentários do Art. 2 ao 20 vai citar além de autores portugueses, franceses e italianos também os germânicos: Savigny, Windscheid, Kohler, Jhering, Dernburg, Bruns-Mitteis, Schirmeister e Prochowick, J.W. Heddemann, Sohm, Roth e o próprio BGB alemão( Code civil Allemand, publié par le Comité de lég. étr.).

75. Paul, in: Stolleis, pg. 63.

76. Pontes de Miranda, Brasil-Codigo Civil, pg. XXXIX.

77. Moreira Alves, José Carlos, A Parte Geral do Projeto de Código Civil Brasileiro, São Paulo, 1986, pg. 6.

78. Bevilaqua, Clóvis, Codigo Civil dos Estados Unidos do Brasil - Commentado, Rio de Janeiro, 1931, pg. 9s. e Pontes de Miranda,Fontes, p. 66.

79. Apud Pontes de Miranda, Fontes, pg. 66

80. Assim Bevilaqua, Clóvis, Em Defesa do Projecto do Código Civil, Rio de Janeiro, 1906, pg. 22ss.

81. Pontes de Miranda, Fontes, pg. 87.

Revista da Faculdade de Direito da UFRGS, v. 13, 1997 ças, em sua maioria, apenas formais. ${ }^{82}$ Somente em $1^{\circ}$ de janeiro de 1917 entra em vigor o Código Civil no Brasil. ${ }^{83}$

\section{Dos primeiros Projetos até o Projeto de 1899 de Clóvis Bevilaqua}

A pergunta sobre a necessidade de uma Codificação do direito civil foi uma constante no Brasil do século XIX. Desde a primeira Constituição Imperial brasileira de 1824 a resposta afirmativa estava clara: um Código Civil Brasileiro deveria ser organizado. ${ }^{84}$ Com este fim, uma série de juristas brasileiros e mesmo portugueses elaboraram estudos e projetos, como os de: Carvalho Moreira (1846), José Homem Correia Telles, Visconde de Seabra, Teixeira de Freitas (1859), Nabuco Araújo(1872), Felício dos Santos(1891) e Coelho Rodrigues (1890). Em abril de 1899 foi contratado Clóvis Bevilaqua, Professor de Legislação Comparada da Faculdade de Direito de Recife, e em menos de oito meses, em novembro de 1899 , estava pronto o Projeto. ${ }^{85}$

Bevilaqua era oriundo da Escola do Recife e muito influenciado pela Pandectística alemã. ${ }^{86}$ Era um organizador pragmático e cuidadoso, e, sobretudo, um

82. Veja crítico, Pontes de Miranda, Fontes, pg. 92.

83. Art. 1.806 do CCBr., Decreto Nr. 3.071 de 10 de Januar de 1916

84. Pontes de Miranda, Fontes, pg. 66.

85. Veja detalhes em Pontes de Miranda, Fontes, pg. 79 a 96 .

86. Pontes de Miranda, Fontes, pg. 83.

87. Veja as críticas de Pontes de Miranda, in: Fontes, pg.86-87: "...é uma codificação para as Faculdades de Direito, mais do que para a vida. O que nele morde (digamos) a realidade vem de Teixeira de Freitas ou de Coelho Rodrigues...há excesso de boa fé, que the advém de não haver advogado, nem ter sido juiz, mas somente professor..."

88. Pontes de Miranda, Brasil- Codigo Civil, pg. XXII. jurista preciso. Sua admiração pela ciência jurídica alemã e por Savigny teve de ceder ao modelo francês já acentado, aos costumes existentes e à necessidade de adaptação de modelos estrangeiros à realidade brasileira. Professor e não advogado, privilegia Bevilaqua uma linguagem curta e precisa, relativamente simples para o mundo do direito, com definições legais precisas e um sistema relativamente exaustivo, que levarão o CCBr. a ser chamado de obra professoral, afastada da realidade. ${ }^{87}$

Segundo Pontes de Miranda o Projeto Bevilaqua e, por conseguinte, o CCBr. apresentam um caráter "sentimental", e menos social do que poderia ser. ${ }^{88}$ Ao contrário, seria o CCBr. marcado pelo indivireligioso-morais que o caracterizariam como texto pouco político, a contribuir para o continuismo da organização social e para aumentar os conflitos sociais. Um bom exemplo seriam as normas sobre a incapacidade civil dos indígenas e as regras sobre a divisão e função da propriedade que ajuimplantado.

As críticas de Rui Barbosa ao Projeto de Bevilaqua tinham natureza formal e linguística, concedendo ao texto legal uma dualismo, com idéias liberais e daram a manter o colonialismo-feudal já 
nova unidade, mas diminuindo a sua precisão científica. Segundo Pontes de Miranda, nos 16 anos de discussão parlamentar sobre o Código perdeu-se a chance histórica de analisar o modelo do novo Código Alemão, o BGB de 1900: "não se folheou o B.G.B..." 89 ! Assim também ocorreu com o Código Civil Suíço (1907) e de Obrigações (1911): "A nenhuma destas leis recorreu o Senado - indiferente, como a Câmara e as Comissões, aos ensinamentos técnicos do século $X X$. De forma a poder afirmar o renomado jurista: A data mental do Código (como do BGB e do suíço) é bem 1899." 90

Efetivamente, o CCBr. pode ser visto como um filho do século XIX. ${ }^{91} \mathrm{~A}$ maior influência alemã neste Código vei através da influência da própria doutrina e ciência alemã do século XIX, a Pandectística alemã e dos dois Projetos para o BGB..$^{92}$

\section{Fontes de inspiração do \\ Projeto Bevilaqua}

Moreira Alves defende a tese que, dos 1807 Artigos do CCBr., cerca de 1445 são produtos da cultura romana, seja diretamente através das fontes romanas e da ciência originada no estudo do direito romano após a idade média, seja indiretamen-

te através de leis que recepcionaram esta cultura, leis portuguesas, alemãs, francesas e italianas. ${ }^{93}$ Clóvis Bevilaqua, por sua vez, identifica em seus Comentários aos Artigos 1 a 114 do CCBr. cerca de 49 Artigos cuja origem é romana, direta ou indiretamente, através da própria Pandectítica alemã. ${ }^{94}$

A mais interessante das estatíticas sobre as fontes de inspiração do $\mathrm{CCBr}$. é apresentada por Pontes de Miranda, sem porém preocupar-se o autor em comprovar suas afirmações. ${ }^{95}$ Afirma o autor que: "Das aproximadamente 1.929 fontes do Código $\mathrm{Ci}$ vil, ao direito anterior pertencem 479, à doutrina já vigente antes do Código Civil, 272,e ao Esboço de Teixeira de Freitas, 189... Dos Códigos, o que quantitativamente mais concorreu foi o code civil,172, menos por si do que pela expressão moderna que dera as regras jurídicas romanas. Em seguida o português,83, o italiano, 72; os Projetos alemães, 66; o Privatrechtliches Gesetzbuch für den Kanton Zürich, 67; o espanhol, 32, a lei suíça de 1881, 31: o Código Civil Argentino, 17 ;o direito romano (diretamente), 19; o BGB austríaco, 7; o Código Civil Chileno,7, o Código Civil mexicano, 4; o uruguaio, 2 ; o peruano, 2 e outros." 96 Segundo estas estatíticas mais

89. Pontes de Miranda, Fontes, pg. 83: "Depois de 51 sessöes, encerraram-se os trabalhos em agosto de 1990. Esta data é expressiva: já se achava em vigor o BGB e a comissão não cotejara sequer o que prevalecera naquele código... 0 governo procedeu a aoutra revisão, ...mas, ainda aí, não se folheou o 0 BGB."

90. Pontes de Miranda, Fontes, pg. 85: "Keine de diese Gesetze wurden benutzt, gleichgültig war das Parlament e die Kommisssionen für die Technick e Wissen der 20. Jahrhundert."

91. Pontes de Miranda, Fontes, pg. 85 e Couto e Silva, pg. 170.

92. Pontes de Miranda, Fontes, pg. 93

93. Moreira Alves, O Direito Romano, pg. 29.

94. So Statistik de Moreira Alves e Gaetano Sciascia, in: Moreira Alves, O Direito Romano, pg. 30

95. Veja Pontes de Miranda, Fontes, pg. 93.

96. Veja Pontes de Miranda, Fontes, pg. 93.

Revista da Faculdade de Direito da UFRGS, v. 13, 1997 da metade da fontes utilizadas foram brasileiras e de autores brasileiros e só 670 (de $1.178)$ oriundas da legislação estrangeira. ${ }^{97}$

Segundo ainda Pontes de Miranda dos Projetos brasileiros o mais original e que maior número de normas inspirou foi o de Teixeira de Freitas, com 189 normas, 49 normas de Felício dos Santos, 154 de Coelho Rodrigues, 135 de Clóvis Bevilaqua, 78 das várias Comissões, 40 da Câmara dos Deputados e 26 do Senado. ${ }^{98}$ A conclusão de Pontes é, portanto, que da influência estrangeira a maior foi, cumulativamente, a germânica, seja através da Pandektistik e indiretamente de sua recepção em autores brasileiros, seja diretamente através dos variados Códigos e Leis da família dos $\mathrm{Di}$ reitos germânicos (deutsche Rechstfamilie) e dos próprios dois Projetos ao BGB. ${ }^{99}$ Para examinar mais detalhadamente esta tese, será necessária uma segunda parte para identificar a influência alemã no Sistema do CCBr.

\section{II - Sistemática do Código Civil Brasileiro de 1916 e o BGB alemão}

Nesta segunda parte do trabalho, gostaríamos de analisar a influência que o BGB exerceu efetivamente no Código Civil Brasileiro de 1916. Segundo a opinião

98. Pontes de Miranda, Fontes, pg. 93

99. Pontes de Miranda, Fontes, pg. 93

100. Zweigert/Kötz, pg. 114 (\$8 VI) e David, pg. 95 (Nr. 67).

101. ZweigertKötz, pg. 114 (\$ $8 \mathrm{VI})$.

102. Pontes de Miranda, Fontes, pg. $97 f$.

103. Bevilaqua, Em Defesa do Projeto, pg. 23: "Uma das suas (do Esboço) mais significativas originalidades é, sem dúvida, a ordem adoptada para a distribuição das materias..."

Revista da Faculdade de Direito da UFRGS, v. 13, 1997 mais corrente, ${ }^{100}$ o CCBr. deve à direta influência alemã a sua sistemática externa, especialmente sua divisão em Parte Geral e Parte Especial. Analisaremos, portanto, em detalhes se a divisão em Parte Geral (A) em Parte Especial (B) realmente tem sua origem na influência germânica em nosso direito, assim como a opinião da doutrina brasileira sobre a influência alemã, seja diretamente pelo $\mathrm{BGB}$, seja indiretamente pela doutrina pandectista, no conteúdo das normas aceitas no $\mathrm{CCBr}$.

\section{A) A inclusão de uma Parte Geral no Código Civil Brasileiro de 1916 e o BGB}

Os autores alemães tendem a considerar que a influência germânica no CCBr. foi quase que exclusivamente quanto ao sistema adotado no Projeto Bevilaqua, especialmente com a inclusão de uma Parte Geral. ${ }^{101}$ Autores brasileiros, ao contrário, consideram que a inclusão de uma Parte Geral no CCBr. deve-se a uma idéia original de Teixeira de Freitas e não a imitação de uma modelo estrangeiro, como o BGB. ${ }^{102}$ Bevilaqua mesmo concorda que a divisão das matérias no Esboço foi uma original contribuição de Freitas ao direito brasileiro. ${ }^{103}$ Da mesma forma, o comparatista fran-

\section{O Sistema da Parte Geral brasileira}


cês René David destaca o importante precedente que representou, no direito brasileiro, a divisão das matérias da "Consolidação das Leis Civis" de 1858, duvidando que a divisão executada no $C C B r$. deva-se a uma direta influência do BGB de 1896. ${ }^{104}$

Segundo Enneccerus-Niepperdey, o $\mathrm{CCBr}$. possui várias idéias originais, mas seu sistema teria forte correlação ou inspiração no BGB alemão:

"La más independiente de las codificaciones latinoamericanas es el C.c. brasileño de $1^{\circ}$ de enero de 1916. De los 1.807 artículos que lo integran, una mitad, más o menos, deriva de los códigos europeus, principalmente del francés y del portugués, habiendo 62 artículos que tienen su origen en el C.c. alemán. La otra mitad se funda en ideas de los juristas brasileños y recoge el derecho consuetudinario." isto porque "metade dele se funda em idéias dos juristas brasileiros e recothe o direito consuetudinário. La ordenación de las materias tiene una amplia correlación con el C.c. alemán, aunque sea diversa la división en una parte general y una parte especial"105 $^{\prime \prime}$

Note-se que, efetivamente, a Consolidação de Teixeira de Freitas possuia já em 1858 uma Parte Geral, a qual incluia, de forma original frente aos modelos da época, normas somente sobre dois temas: Das Pessoas e.Das Cousas. ${ }^{106}$ Em sua Introdução à Consolidação das Leis Civis, esclarece Freitas de forma exaustiva e independente, porque ele recusa os dois modelos em voga, tanto o modelo do direito romano, a divisão das Institutas de Caio, ${ }^{107}$ quanto o modelo do Code Civil ${ }^{108}$ francês e porque não organiza sua Consolidação segundo a divisão clássica "pessoas-coisas-ações", mas em duas partes distintas: a Parte Geral e a Parte Especial do Direito Civil. A inspiração para incluir uma Parte Geral é retirada por Freitas de um texto romano. 109

Em sua procura, que nos parece crítica e independente, da melhor divisão das matérias, Freitas cita igualmente Savigny, mas conclui que, a esta época (a Consolidação foi elaborada entre 1855 e 1858), a Escola Histórica alemã ainda não teria chegado a um consenso sobre a melhor divisão das matérias. ${ }^{110}$

104. David, pg. 95 e Fußnote 1, pg. 95 (Nr. 67).

105. Ennecerus, Nipperdey, pg. 109 ( $(26$ X). Contra Moreira Alves, José Carlos, O Direito Romano, pg. 28.

106. Freitas, Introdução, pg. CXII e CXIII: "Sob as idéias fundamentaes, que temos desenvolvido, a Consolidação das Leis Civis apresetna em sua primeira divisão duas grandes categorias, que fórmão sua Parte Especial. Á esta Parte Especial antecede uma Parte Geral, que lhe serve de prolegomenos. A Parte Geral trata em dois Titulos das pessoas e das cousas, que são os elementos constitutivos de todas as relaçōes juridicas, e portanto, das relaçōes juridicas na esphera do Direito Civil."

107. Freitas, Introdução zur Consolidação das Leis Civis - Publicação Autorizada pelo Governo, 3. Ed., Rio de Janeiro, 1896, pg. XLe XLI:"Nas Institutas, destinadas ao ensino, a pretendida normas devêra ter sido rigorosamente observada. tambem isto não se confirma....Esta incoherente distribuição de materias..."

108. Freitas, Introdução, pg. LII e LIV: "Com muita razão se tem dito que a ultima divisăo do Codigo Civil Francez poderia ter comprehendido todas as leis civis, e que o tratado das pessoas e das cousas não passa de simples preliminar... Não obstante seu methodo artificial... o Codigo Civil da França tem exercido poderosa influencia."

109. Freitas, Introdução, pg, XL: "Omne jus vel ad personas pertinet, vel ad res, vel ad actiones" (Dig. L. 1 de stat hom., Inst. L. 1.T. 3.princ, Inst. Gaio Comment. 1. N. 8).

110. Freitas, Introdução, pg. LII, veja citações de Savigny, pg. XLI, L, e de Leibnitz, pg. XLIX,L e LI. Analisado foi também o Código Austríaco (ABGB), pg. LVI.

Revista da Faculdade de Direito da UFRGS, v. 13, 1997
Teixeira de Freitas propõe em seu "Esboço" de 1860, por sua vez, a divisão do direito privado nas seguintes partes: Parte Geral (Pessoas, Coisas, Fatos), e uma Parte Especial dividida em direitos pessoais (em geral, relações de família e relações civis), direitos reais (em geral, sobre coisas próprias e sobre coisas alheias) e disposições comuns a pessoas direitos pessoais e reais (herança, concurso de credores e prescrição). ${ }^{111}$ Nota-se em Freitas já grande influência de Savigny, mas os autores brasileiros são unânimes ao considerar que, na divisão escolhida para o Esboço, manteve Freitas posição se não perfeita, pelo menos original, afirmando Pontes de Miranda:"Porém o mais admirável é a solidez, o concateamento e a intereza da construção jurídica, com que pode erguer, com tal programa falho, com tal classificação censurável, a sua obra minudente, sagaz, em que por vezes se advinha o que só no $B G B$ aparecerá. E só este Código (BGB) é, ainda hoje, pelo rigor técnico, superior ao Es. boço brasileiro de 1860."

O próximo Projeto de Código foi elaborado por Coelho Rodrigues(1890/91). Coelho Rodrigues subdivide as matérias,

inspirado por Freitas, em Parte Geral e Parte Especial. A Parte Geral de Coelho Rodrigues, porém, inclui normas sobre: 1.Pessoas (físicas e jurídicas, brasileiros e estrangeiros, domicílio ), 2.Coisas; 3."Dos actos e factos jurídicos" ("Factos Jurídicos: necessarios (nascimentos, obitos); eventuais (pericimento da cousa, prescripção, actos illicitos); Actos Juridicos: relativos aos direitos reaes; relativos aos direitos pessoaes; formas dos actos juridicos e as provas legaes."). ${ }^{112}$

Em sua Introdução ao Projeto esclarece Coelho Rodrigues a originalidade de sua idéia de incluir uma terceira divisão na Parte Geral referente aos Actos jurídicos. ${ }^{113}$ O autor analisa o obra de Savigny, e o critica por incluir no conceito de "Factos Jurídicos" não somete os fatos objetivos, mas também algumas declarações de vontade, que pela participação do homem deveriam estar contidas nos atos jurídicos..$^{114}$ Conclu Coelho Rodrigues que sua terminologia é a melhor e critica não só a posição de Savigny, mas também o "novo projeto alemão", referindo-se ao Projeto de BGB de 1987/88 e a posição das normas sobre prescrição e decadência. ${ }^{15}$ As idéias principais de Coe-

111. Pontes de Miranda, Fontes, pg. $97 \mathrm{~s}$

112. Coelho Rodrigues, A. Projecto do Codigo Civil precedido da Historia Documentada do mesmo e dos anteriores, Rio de Janeiro, 1897, pg. 7.

113. Coelho Rodrigues, pg. 6 e 7:" 7. Pelos meiados de 1885...esbocei o plano do 'Appendice B e apresentei-th'o no fim de julho daquelle anno.....Nelle propunha eu, ...que o projecto fosse dividido em uma parte geral e outra parte especial; que a primeira fosse subdividida em tres livros: um das Pessoas, outro das Cousas e outro dos Actos Jurídico, ...8. Foi sob a influencia destas idéas que, um anno depois, assentei o plano...mencionando, porém, antes dos Actos, os Factos jurídicos, como materia integrante do livro $3^{\circ}$ da Parte Geral, sobre cujo conteúdo divergem autoridades de maior peso...'

114. Coelho Rodrigues, pg. 7. O Autor cita no vol. 3, § 104 o sistema.

115. Coelho Rodrigues, pg. 7: "Mas os factos juridicos, que podem interessar e mesmo resolver tanto os direitos pessoaes, como 0 perecimento do objeto, ou a prescrição do título do direito e os actos illícito in genere, esses só podiam e deviam entrar onde os colloquei, na Parte Geral, sem embargo da opiniâo de Savigny e do exemplo recente do projeto do Codigo civil alemão, que scindiu a materia de prescrição. Nesta parte, portanto, mantive o meu plano e na mesma ordem em que esbocei no contrato $\mathrm{e}$, por ocasião de articulal-o, não encontrei difficuldade imputavel a defeito delle, cujo conteúdo póde ser figurado no seguinte quadro: 
lho Rodrigues, no que se refere à Parte Ge ral do Código Civil, acabaram por influenciar Bevilaqua, o qual, porém, não as adotou totalmente.

A divisão escolhida por Bevilaqua, que é a divisão do atual $C C B r$., foi a seguin te: 1 . Pessoas (das pessoas naturais e jurídicas; do domicílio civil); 2. Bens; 3. Fatos Jurídicos (dos atos jurídicos, dos atos ilícitos, da prescrição). ${ }^{116}$

Esta divisão encontraria sua inspiração nos projetos de Teixeira de Freitas e de Coelho Rodrigues, mas também na legislação comparada e na ciência jurídica da épo$\mathrm{ca}$, segundo Bevilaqua. ${ }^{17}$ Certo é, que mesmo se concordamos com a originalidade das idéias de Teixeira de Freitas na divisão da Parte Geral frente aos modelos estrangeiros, não se pode negar que a obra de Savigny influenciou tanto Freitas, Coe- lho Rodrigues, como Bevilaqua, que a estudaram, discutiram, refletiram e dela se ocuparam enquanto escreviam seus projetos. Freitas e Rodrigues elaboraram seus Projetos antes de que o projeto final do BGB estivesse pronto e consideraram somente 0 primeiro e criticado projeto de $1887 / 88 .{ }^{118}$ Bevilaqua, ao contrário, conhecia o segundo Projeto de BGB, publicado em $1895^{119}$ e o considerou em seus estudos. Parece-nos, maior no Código Civil brasileiro foi a da doutrina alemã, da ciência jurídica alemâ do século XIX e não a inspiração direta retirada dos Projetos ou do próprio BGB de 1896. ${ }^{120}$

\section{Influência do BGB no conteúdo da Parte Geral}

A Parte Geral do CCBr. contém, em comparação com o BGB e tendo em vista a porém, data maxima venia que a influência

\section{Parte Geral}

- Factos Jưrídicos - necessarios (nascimentos, obitos)

- eventuais (pericimento da cousa, prescripçáo, actos illicitos)

Actos Juridico

- relativos aos direitos reaes

- relativos aos direitos pessoaes

A materia do quadro supra adicionei mais um titulo final sobre as formas dos actos juridicos e as provas legaes."

116. Bevilaqua, Em Defeza do Projecto, pg. 26. É interessante notar que Bevilaqua concordava com Savigny, de que as normas sobre "Decadência" deveriam estar na Parte Especial e não reunidas com as de prescriçăo na Parte Geral. O Projeto de CCB foi reformado no Senado neste tema. Pontes de Miranda, Fontes, pg. 86. Veja também meu artigo "Tendances récentes de prescription extinctives en droitbrésilien", in: Hondius Ewoud, Extinctive Prescription-On the Limitation of Actions-. Hague, 1995, pg. 75 ss.

117. Bevilaqua, Em Defeza do Projecto, pg. 26: "Principalmente o Esboço de Teixeira de Freitas e o Projecto do Dr. Coelho Rodrigues, mais seguidamente este que aquelle, forneceram-me copioso elementos para a construçãao que me havia sido confiada. além destes materiaes, aos quaes eu intencionalmente queria ligar o meu trabalho, é natural que pedisse á jurisprudência patria as peculiaridades aproveitaveis de sua feição,á doutrina e á legislação comparada, os seus inestimaveis ensinamentos."

118. Sobre o primeiro Projeto de BGB veja a edição especial da Revista fundada por Savigny, Archiv des civilistische Praxis, Bd. 33, 1888, pg. 1 a 474

119. Veja detalhes em Laufs, Adolf, Rechtsentwicklung in Deutschland, 3.Aufl, Berlin, 1984, pg. 261

120. Bevilaqua, Em Defeza do Projecto, pg. 48: "Dizem alguns que a classificação allemã é puramente empirica...Mas a opinião hoje dominante é, ao contrario, que essa classificação fórma um systema logicamente constituido, em que os diversos membros se prendem e se completam, sem se prejudicarem e sem se confeirem...Tal critério faz-nos encontrar as quatro categorias de relaçóes indicadas sob a denominação de direitos da família, das cousas, das obrigaçóes e das sucessões."

Revista da Faculdade de Direito da UFRGS, v. 13, 1997 possível influência alemã, uma série de normas e conceitos bastante originais. Assim, por exemplo, traz o Código Civil Brasileiro uma Teoria do Ato Jurídico, que na terminologia alemão é chamada de Handlungslehre, e que ficou ausente no BGB de 1896. Note-se que Bevilaqua não utilizou o conceito de "Rechtsgeschäft" (negócio jurídico) ${ }^{121}$, preferindo a expressão tradicional portuguesa de "acto jurídico" (Rechtshandlung) ${ }^{122} \mathrm{e}$, talvez por esta razão, elaborou uma verdadeira teoria do ato jurídico, que incluia não somente o ato lícito, mas também o ato ilícito, seguindo assim os modelos de Freitas e de Coelho Rodrigues. ${ }^{123}$

O BGB trata do negócio jurídico (Rechstgeschäft, § 104 e seg. BGB), da declaração de vontade (Willenserklärung, $\$ 116$ e seg. BGB) e do contrato (Vertrag, § 145 e seg. BGB) na Parte Geral, deixando para a Parte Especial, no Direito das Obrigações, as regras sobre os atos ilícitos e a responsabilidade dai resultante ( $\$ 812$ e seguintes do BGB). O CCBr. define tanto o ato lícito

(atos jurídicos, Art. 81ss.), como o ilícito (atos ilícitos, Art. 159s.), e os fatos juridicamente relevantes (fatos, Art. 74ss.; prescrição, Art. 161ss.) na Parte Geral, como queriam mesmo alguns críticos do BGB.

A doutrina brasileira, porém, tende a utilizar o conceito germânico de negócio jurídico, classificando os atos jurídicos conforme o poder formativo e definidor (Gestaltungskraft) da declaração de vontade presente neste ato, classificando-os em "ato jurídico stricto sensu, ato-fato, negócio jurídico etc.". ${ }^{124}$ A inspiração da doutrina alemã do século XIX e do próprio $B G B$ é aqui inegável. ${ }^{125} \mathrm{~A}$ influência da ciência jurídica alemã e do BGB na literatura atual brasileira é até hoje decisiva, no que se pode chamar de um novo germanismo. Dentre os novos germanistas Pontes de Miranda, ao traduzir o CCBr. para o alemão, chega mesmo a traduzir a expressão "acto jurídico" como "Rechstgeschäft" (negócio jurídico) ${ }^{126}$ A tradução de Pontes da definição legal de ato jurídico para o alemão foi a seguinte: "Art. 81 - Jede erlaubte Handlung, die

121. Bevilaqua não utiliza, nem no Projeto, nem em seus comentários o conceito de "negócio jurídico"; conceito que conhecia , como

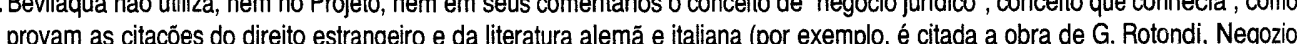
provam as citaçóes do direito estrangeiro e da literatura alem
Juridico), veja Bevilaqua, Codigo Civil, pg. $318 s s$. (Art. 81 ss.).

122. Bevilaqua apoia-se na doutrina brasileira, em Freitas e no Código Civil argentino, afirmando: "O Codigo Civil allemão não definiu 0 acto juridico. 0 francez não destaca esta energia propulsiva da vida juridica.", veja Bevilaqua, Codigo Civil, pg. 318 (Art. 81, Legislaçäo comparada).

123. Art. 81 do CCBr. foi praticamente copiado do Art. 271 do Projeto de Coelho Rodrigues. Previa o Art. 271 de Rodrigues : "Considera-se acto juridico todo o acto lícito que tenha por fim immediato adquirir, conservar, modificar, ou extinguir um direito." O Art. 81 de Bevilaquas e do atual CCBr. dispōe: "Todo acto lícito, que tenha por fim immediato adquirir, resguardar, transferir, modificar ou extinguir direito, se denomina acto juridico"

124. Veja por exemplo a obra do atual Professor der Faculdade de Direito de São Paulo Azevedo, Antonio Junqueira de, Negócio Jurídico - Existência, Validade e Eficácia, São Paulo, 1990 e da atual escola de São Paulo (USP), veja Miranda, Custódio Ubaldino , Interpretação e Integração dos Negócios Jurídicos, São Paulo, 1989.

125. Veja a obra de 60 volumes de Pontes de Miranda, Tratado de Direito Privado, na qual o vol. 3 é dedicado ao "Negócio Jurídico". Sobre o tema, comenta Paul, in: Stolleis, pg. 497.

126. Veja Pontes de Miranda, Brasil - Codigo Civil, pg. 24. 

do Art. $81 \mathrm{CCBr}$. lhe é em muito semelhanaproximar o gênero da espécie. A decisão zum unmittelbaren Zweck hat, Rechte zu erwerben, zu bewahren, zu übertragen, $z u$ verändern oder $z u$ aufzuheben, wird Rechtsgeschäft gennant." 127

Sem dúvida, a utilização que faz a doutrina brasileira atual do conceito alemão de negócio jurídico é correta, pois o domínio do conceito apresenta uma série de vantagens e a definição de ato jurídico lícito te, tanto na estrutura, como nos elementos, pois o negócio jurídico alemão também é uma declaração de vontade dirigida a um "efeito jurídico". ${ }^{128}$ Considerar-lhes, porém, como sinônimos ou fenômenos idêntico pode ser uma simplificação exagerada, a de Freitas, Coelho Rodrigues e Bevilaqua de incluir uma Teoria do Ato Jurídico na Parte Geral, e não somente regras sobre negócios jurídicos, mostrou-se na prática sábia. O sistema da Parte Geral do CCBr ganhou com isto em originalidade e em pragmatismo, pois o domínio da pirâmide de conceitos, do sistema estrito científico da doutrina alemã do século XIX nem sempre é fácil ou acessível a todos.

Por fim, cabe mencionar que mesmo apresentando o CCBr. um sistema causal e

não conhecendo o princípio da abstração alemão (Abstraktionsprinzip), Bevilaqua recusou o modelo francês de incluir nos pressupostos de validade do ato (art. $82 \mathrm{CCBr}$.) expressamente a causa lícita ( cause). ${ }^{129}$ Somente no Art. 90 do Código brasileiro há menção expressa à causa como motivo de nulidade relativa do ato. A noção de causa está, porém, implícita no sistema do direito civil brasileiro e lhe domina como os writs do antigo direito inglês, sendo uma constante na jurisprudência e na literatura brasileira. ${ }^{130}$

Uma outra característica considerada positiva da Parte Geral des CCBr. é ter utilizado para definir o ato ilícito de uma cláusula geral, recusando o modelo alemão do § 823 BGB (unerlaubte Handlung) de estrita previsão positiva dos bens lesados a dar razão à indenização por ato ilícito. $\mathrm{O}$ Art. 159 CCBr. prefere o modelo francês e baseando-se no princípio comum da culpa. A opção por uma cláusula geral e a consciente recusa do princípio francês do noncumul, que proíbe a cumulação de pretensões de origem contratual e extracontratual, parecem ter contribuido decisivamente para o bom desenvolvimento da responsabilidade extra-contratual no direito brasileiro.

127. Pontes de Miranda, Brasil - Codigo Civil, pg. 24.

128. Assim ensina Planck, que em sua obra de 1897, afirmava: "Rechtsgeschäft ist eine Privatwillenserklärung gerichtet auf die Hervorbringung eines rechtlichen Erfolges, welcher nach der Rechtsordnung deswegen eintritt, weil er gewollt ist." Planck, B. Bürgerliches Gesetzbuch, Bd.I, 30 Ediçăo, Berlim, 1903, pg. 179.Veja a tradução de Westerman, Harry, Código Civil AlemãoBürgerliches Gesetzbuch, Bd.I, 30 Ediçăo, Berlim,
Parte Geral, Fabris, Porto Alegre, 1991, pg. 101ss.

129. Veja Bevilaqua, Codigo Civil, pg. 321 (Art. 82) e 331 (Art. 90): A causa dos contratos...A doutrina já fez justiça a esse requisito, que parece ter entrado no Codigo Civil francez por um equivoco... 0 codigo civil argentino, allemáo, portuguez e o federal suisso das obrigações não mencionam a causa entre os requisitos dos actos juridicos." (pg. 331).

130. A causa é recolocada no sistema do CCBr. através da interpretaçăo doutrinária e jurisprudencial "Objeto lícito". Veja por todos, Costa, Judith Martins, A Teoria da Causa em perpectiva comparatista: a causa no sistema civil francês e no sistema civil brasileiro, in: Revista AJURIS 45 (1989), pg. 25ss. Contra Bevilaqua, Codigo Civil, pg. 331.
Ao contrário, é considerada uma característica negativa da Parte Geral do CCBr. não possuir normas gerais semelhan tes os $§ 138$ BGB (violação dos bons costumes) ${ }^{131}$ e $\$ 157$ BGB (interpretação conforme a boa-fé e aos bons costumes) ${ }^{132}$. O Código Civil brasileiro recebeu uma sé rie de noções do direito romano, como o dolus malus (dolo do Art. 92ss.), o metus (coação do Art. 98ss.), a exceptio doli contractus,etc., mas a idéia de nulidade dos atos jurídicos contra bonos mores não foi expressamente prevista, restando apenas implícita. Da mesma forma as normas sobre interpretação dos negócios jurídicos são poucas, valorizando a vontade interna daquele que declara (Art. $85 \mathrm{CCBr}$.), ${ }^{133} \mathrm{Os}$ valores liberais e individualistas da época encontram aqui sua expressão no CCBr., o que Pontes de Miranda considera uma conseqüencia da "ingenuidade" de Bevilaqua, um professor e não um advogado. ${ }^{134}$ Contra estas críticas se pode afirmar que apesar das cláusulas gerais de boni mo- res (comparável ao $\S 138 \mathrm{BGB}$ ) e de bona fides (comparável ao $§ 242$ BGB, que encontra-se no direito das obrigações) não estarem expressas no $\mathrm{CCBr}$., estão implícitas em seu sistema. ${ }^{135} \mathrm{Da}$ mesma forma, não há porque criticar a escolha de Bevilaqua pela Teoria da Vontade (Willenstheorie) se no final do século XIX as teorias subjetivas eram prevalentes ${ }^{136}$ e mesmo o direito alemão teve de fazer alguns compromissos entre a Teoria da Vontade e da Declaração. ${ }^{137}$

Segundo Bevilaqua, a Parte Geral do $\mathrm{CCBr}$. recebeu em suas normas grande in fluência da Pandectística alemã. Bevilaqua destaca o Art. $74 \mathrm{CCBr}$., sobre aquisição de direitos, que teriam sua origem na obra de Savigny; $;^{138}$ a noção de ação em direito material do Art. $75 \mathrm{CCBr}$., baseada no conceito alemão de Anspruch ${ }^{139}$ e outros. ${ }^{140} \mathrm{Em}$ seus comentários, Bevilaqua deixa clara a forte influência que exerceu a ciência e doutrina alemã do século XIX no contéudo da Parte Geral do CCBr., assim como foi forte a influência do direito tradicional brasilei-
131. O texto do § 138 BGB é o seguinte: " Um negócio jurídico que infrija os bons costumes é nulo.

Nulo é, especialmente, o negócio jurílico pelo qual alguém, explorando o estado de necessidade, a situação ou a inexperiência do outro, faz prometer ou conceder, para si, ou para terceiro, contra uma prestação, vantagens patrimoniais das quais o valor exceda de tal modo à prestação que, de acordo com as circunstâncias, as vantagens patrinominiais estão em manifesta desproporção com a prestação. " (traduçăo de Souza Diniz, Código Civil Alemăo, Record, Rio de Janeiro, 1960, pg. 40).

132. O texto do § 157 BGB é o seguinte: "Os contratos devem ser interpretados conforme as exigências da boa-fé, atendendo-se aos bons costumes." (tradução nossa).

133. Veja Bevilaqua, Codigo Civil, pg. 324f (Art. 85). Sobre a importância do sistema de interpretaçáo da vontade no BGB, veja Schmoeckel, Mathias, 100 Jahre BGB: Erbe und Aufgabe, in: NJW 1996, pg. 16991

134. Veja as críticas de Pontes de Miranda, Fontes, pg. 87.

135. Veja Couto e Silva, Clóvis, O Princípio da Boa-Fé no Direito Brasileiro e Português, in: Couto e silva, Clóvis (Coord.), Estudos de Direito Civil Brasileiro e Português, São Paulo, 1980, pg. 43ss.

136. Veja detalhes em Junqueira, pg. 6 .

137. Kötz, Hein, Europäisches Vertragsrecht I, Tübingen, 1996, pg. 165 (\$7)

138. Bevilaqua, Codigo Civil, pg. 310 (Art. 74, 2)

139. Bevilaqua, Codigo Civil, pg. 311 (Art. 75,1)

140. Segundo Pontes de Miranda encontram-se na Parte Geral do CCBr. outras influências materiais do direito alemãos, tais como Art. 20 CCBr., o Art. 26ss. CCBr. e o .Art. 32 CCBr., entre outros. Veja Pontes de Miranda, Fontes, pg. 133 até 164. 
ro e português, e dos Projetos de Freitas e de Coelho Rodrigues.

Concluí-se, portanto, que as regras da Parte Geral do CCBr. sobre fatos e ato jurídicos retiraram forte inspiração da doutrina pandectista alemã. Assim também indiretamente, receberam alguma influência do próprio $\mathrm{BGB}$, mas não seguem as normas brasileiras a estrita construção conceitual (strenge Begriffskonstruktion), nem se tentou incorporar estes conceitos ao direito positivo brasileiro. ${ }^{141} \mathrm{O} \mathrm{CCBr}$. deveria manter-se original, com técnica semelhante chegar a resultados comparáveis, sem ter que adotar o sistema de conceitos do direito alemão no nascente direito civil positivo brasileiro.

\section{B) A inclusão de uma Parte Especial no Código Civil Brasileiro de 1916 e o BGB}

\section{O Sistema da Parte Especial \\ brasileira}

A divisão da Parte Geral do CCBr. encontra sua origem, segundo Bevilaqua, nos Projetos de Teixeira de Freitas e de Coelho Rodrigues, assim como na legislação comparada e na doutrina da época. ${ }^{142}$

Teixeira de Freitas propôs um código unificando as obrigações civis e comerciais, portanto, seus Esboço só pôde ser considerado em alguns aspectos. Note-se que tanto Freitas, como Coelho Rodrigues elaboraram seus projetos antes que a versão final do BGB (Projeto II de 1895) ${ }^{143}$ estivesse pronta. Bevilaqua, ao contrário, pode considerar tanto o primeiro - e rejeitado- Projeto alemão de $1887 / 88^{144}$, como o segundo e definitivo Projeto de 1895, uma vez que elaborou seu texto em 1899.

Sobre o sistema escolhido, declara Bevilaqua ter adotado a "classificação alemã" e afirma: "Dizem alguns que a classificação allemã é puramente empirica... Mas a opinião hoje dominante é, ao contrario, que essa classificação fórma um systema logicamente constituido, em que os diversos membros se prendem e se completam, sem se prejudicarem e sem se confundirem... Tal critério faz-nos encontrar as quatro categorias de relações indicadas sob a denominação de direitos da família, das cousas, das obrigações e das sucessões." ${ }^{145}$ Bevilaqua esclarece que a época não havia posição científica prevalente, pois de um lado o sistema de Savigny iniciava com o Direito das Coisas, já Coelho Rodrigues de forma original ${ }^{146}$ e o próprio

\section{Veja Bevilaqua, Codigo Civil,pg. 320 (Art. 82 CCBr.).}

142. Bevilaqua, Em Defeza do Projecto, pg. 26: "Principalmente o Esboço de Teixeira de Freitas e o Projecto do Dr. Coelho Rodrigues, mais seguidamente este que aquelle, forneceram-me copioso elementos para a construçãao que me havia sido contiada. além destes materiaes, aos quaes eu intencionalmente queria ligar o meu trabalho, e natural que pedisse a jurisprudência patria as peculiaridades aproveitaveis de sua feição,á doutrina e á legislação comparada, os seus inestimaveis ensinamentos."

143. Veja detalhes in: Laufs, pg. 261.

144. Veja detalhes sobre a crítica este primeiro Projeto e sua rejeiçăo, in: Hattenhauer, Hans, Die geistesgeschichtlichen Grundlagen des deutschen Rechts, Heidelberg, 1983, pg. 172 (N. 360).

145. Bevilaqua, Em Defeza do Projecto, pg. 48.

146. Coelho Rodrigues, pg. 9.0 autor esclarece a originalidade de sua idéia e informa que após recebeu tradução do primeiro Projeto de BGB de 1887788 elaborada pelo Professor de Genebra Louis Bridel: "Realizadas estas alteraçōes ainda não fique satisfeito...porque não conhecia uma autoridade notoria, que me apoiasse nesta inovação e receiava passar por original em
BGB (em ambos os Projetos) iniciavam com o Direito das Obrigações ${ }^{147}$, enquanto o Código asutríaco (AGBGB) e o Projeto suíço começavam com o Direito de Família. ${ }^{148} \mathrm{Na}$ falta de consenso, opta Bevilaqua por regular inicialmente o "cerne" da sociedade, a família, marcando assim o sistema da parte Geral brasileira com certa originalidade. ${ }^{149}$

O sistema do CCBr. é o seguinte Parte Geral (Art. 1-179), Parte Especial (180-1805), dividida em quatro livros: Di reito de Família (Art. 180-484), Direito das Coisas (Art. 485-862), Direito das Obriga ções (Art. 863-1571), Direito das Suces sões (Art. 1572-1805).

O sistema do CCBr. aproxima-se efe tivamente do sistema do $\mathrm{BGB}^{150}$, o qua Bevilaqua chama de "sistema allemão"151, mas as importantes diferenças autorizam concluir que a influência decisiva foi a da doutrina e ciência pandectística alemã e só indiretamente, e com muito menor força do $\mathrm{BGB}$ e seus projetos.

\section{Influência do BGB no conteúdo da Parte Especial}

O Direito de Família brasileiro, Livro I da Parte Especial do CCBr. encontrase em contínua evolução. Do direito de família previsto no Projeto de Bevilaqua resta muito pouco no direito de família brasileiro de hoje, apesar da maioria das normas permanecer em vigor, seu espírito, sua releitura conforme a Constituição, e mesmo seu teor, em muito se modificou. Fenômeno semelhante aconteceu com a parte de direito de família do BGB. ${ }^{152}$ As normas de direito de família previstas originariamente em ambos os códigos eram conservadoras e representativas do pensamento moral do século XIX. ${ }^{153} \mathrm{O}$ direito de família do CCBr., previsto em 1899, tinha como origens o direito português, os costumes e a tradição brasileira e forte influência francesa e italiana. ${ }^{154} \mathrm{~A}$ influência dos projetos alemães restringiu-se aos temas da filiação e da pretensão a alimentos. ${ }^{155}$

materia de tanta responsabilidade. Felizmente, communicando meus desejos e receios a um distincto professor da Faculdade de Direito de Genebra, elle não só approvou a minha idéa, como apoiou-a com o exemplo do Projecto do Codigo Allemão, cujo indice teve a bondade de traduzir em francez para mais tranquillizar-me."( Coelho Rodrigues, pg. 9f.)

147. Veja sobre a divisão da parte especial do primeiro Projeto alemão de BGB, AcP 33(1888), pg. 209ss.

148. Bevilaqua, Em Defeza do Projecto, pg. 47-49.

149. Bevilaqua, Em Defeza do Projecto, pg. 52. Note-se que a primeira versão do Projeto de Coetho Rodrigues trazia ordem semeIhante das matérias, veja Coelho Rodrigues, pg. 7.

150. Parte Geral (Pessoas, Coisas, Negócios Jurídicos, Prazos, Prescrição, Exercício dos Direitos, Garantia - § 1 a 240), Direito das Obrigaçōes (§ 241 a 853); Direito das Coisas ( 8854 a 1296), Direito de Família ( $(1297$ a 1921); Direito das Sucessōes ( $\$ 1922$ a 2385).

151. Bevilaqua, Em Defeza do Projeto, pg. 50.

152. Veja Stürner, Rolf, Der hunderste Geburtstag des BGB - nationale Kodifikation im Greisenalter?, in: JZ 1996, pg. 747 (pg. 741 752). Veja também Bosch, F.W., Entwicklunglinien des Familienrechts in den Jahren 1947 bis 1987, in: NJW 1987, pg. $2617 \mathrm{ss}$. Sobre a necessária evoluçāo do direito alemăo veja a expressiva de Kohler, já em 1906: "... Das Bürgerliche Gesetzbuch darf nicht Sobre a necessária evoluçăo do direito alemão veja a expressiva de Kohler, ja em 1906: “...Das Bürgerliche Gesetzbuch dart nicht
aư Jahrzehnte lang Hemmnis freier Wissenschaft und freier weitschauender Rechtsprechung sein,... Nur im Fortschritt ist das auf Jahrzehnte lang Hemmnis freier Wissenschaft und freier weitschauender Rechtsprech
Leben" (Kohler, Josef, Lehrbuch des Bürgerlichen Rechts- Bd.1, Berlin, 1906, pg. 7 e XIl.

153. Veja Pontes de Miranda, Fontes, pg. 166 sobre o CCBr. e Störner, pg. 747 sobre o BGB

154. Veja Pontes de Miranda, Fontes, pg. 167.

155. Pontes de Miranda, Fontes, pg. 174 
No direito das coisas, é necessário frisar que a Teoria da posse (Besitztheorie) de Savigny, aceita no direito anterior e por Teixeira de Freitas e Coelho Rodrigues, foi recusada por Bevilaqua com base na Teoria de Jhering. ${ }^{156} \mathrm{O}$ Art. $486 \mathrm{CCBr}$. deveria prever esta recusa da Teoria subjetiva de Savigny e o Art. 485 CCBr. introduzir no direito brasileiro positivo a teoria de Jehring. ${ }^{157}$ Tais normas, porém, não foram totalmente compreendidas pela prática, não conseguindo o direito brasileiro superar totalmente as discussões sobre animus possidendi e o corpus . ${ }^{158}$ Da mesma forma, identificamos nas regras sobre a alieno nomine uma forte influência alemã. ${ }^{159}$

O sistema de transferência da propriedade de bens móveis e de imóveis no Brasil é o do titulus e do modus. Neste sentido, exige o Art. 620ss. a tradição, enquanto o Art. 530ss. exige para a transferência dos direitos reais sobre bens imóveis, o competente registro da escritura de compra e venda. ${ }^{160}$ Originais são as regras dos Artigos 647 e 648 CCBr. com sua noção de "Propriedade Resolúvel", elaborada por Freitas (Art. 4.310-4.313 do Esboço). ${ }^{161}$ Estas normas encontram-se relacionadas com o Art. $622 \mathrm{CCBr}$., que permite uma "schwebende

unwirksame" tradição do non domino. Assim alcança o sistema do CCBr. a importante separação (Trennung) entre o negócio obrigacional (Verpflichtungsakt), no caso o titulus ou a causa, e os efeitos do ato real de transmissão(Verfügungsaktes), no caso de móveis, a tradição. Esta separação visa a proteção do tráfico jurídico (Rechtsverkehrs), do mercado e dos terceiros, como o próprio princípio alemão da abstração (Abstraktionsprinzip), sem porém aceitá-lo expressamente e com todas as suas conseqüencias. $\mathrm{O} \mathrm{CCBr}$. de Bevilaqua e Freitas é um sistema causal. ${ }^{162}$

OCCBr. opta por reconhecer ao contrato de compra e venda somente efeitos obrigacionais, originando-se do Art. 1122 CCBr. ipso iure nenhum direito real, o que, se tivéssemos seguido o princípio francês do solo consensus, seria possível. Na maioria dos tipos contratuais reconhece o $\mathrm{CCBr}$. apenas pretensões obrigacionais ao credor, ${ }^{163}$ seguindo o modelo romano da obligatio. ${ }^{164}$

Em Direito das Obrigações, Livro III da Parte Especial identifica a doutrina brasileira decisiva influência da ciência jurídica alemã do século XIX, do segundo projeto de BGB e da Lei suíca de $1881,{ }^{165}$ nos seguintes artigos e institutos: a força

156. Bevilaqua, Em Defeza do Projecto, pg. 108ss. Veja detalhes em Pontes de Miranda, Fontes, pg. 183f.

157. Bevilaqua, Em Defeza do Projecto, pg. 109.

158. Pontes de Miranda, Fontes, pg. 184

159. Pontes de Miranda, Fontes, pg. 187.

160. Veja CCBr. und Pontes de Miranda, Fontes, pg. 189

161. Veja Pontes de Miranda, Fontes, pg. 191.

162. Bevilaqua, Em Defeza do Projecto, pg. $127 f$.

163. Veja detalhes em Pontes de Miranda, Fontes, pg. 272-335.

164. Veja Kaser, pg. 343.

165. Pontes de Miranda, Fontes, pg. 250ss. e Bevilaqua, Em Defeza do Projecto, pg. 129. Bevilaqua esclarece sua posição indepen-

dente: "Tendo em consideração esses motivos de oredem logica, afastei-me do methodo seguido pelo codigo civil allemão e pelo

Revista da Faculdade de Direito da UFRGS, v. 13, 1997 vinculativa da proposta do Art. 1.080 CCBr. (comparável com o $§ 145$ ss. BGB) ${ }^{166}$, a manifestação de vontade unilateral como fonte de obrigação no Art. 1079 ss. CCBr. ${ }^{167}$, o arras do Art. 1.094 (comparável com o $\S$ $336 \mathrm{BGB})^{168}$, a estipulação em favor de terceiro do Art. 1.098ss. CCBr. (comparável com o $§ 328$ ss. BGB) ${ }^{169}$, a gestão de negócios sem mandato do Art. 1.332 CCBr. (comparável com o $\$ 678$ BGB) ${ }^{170}$, a solidariedade e a pluralidade de credores dos Art. 899ss. CCBr. (com soluções comparáveis a dos $§ 428$ ss. BGB) ${ }^{171}$, as regras sobre pagamento dos Art. 930ss. CCBr. (com soluções comparáveis a dos $\S 362$ ss. BGB), ${ }^{172}$ o princípio dos Art. 1056ss. CCBr., segundo o qual da inexecução total ou parcial das obrigações resultam perdas e danos (comparável com o Art. 110 da lei suíça de 1881) e a cessão de crédito do Art. $1065 \mathrm{CCBr}$. (comparável com a solução da lei suíça de $1881)^{173}$ etc.

O Direito das Sucessões, Livro IV da Parte Especial do CCBr., foi bastante criti- cado: suas normas seriam simples em demasia e criariam na prática um regime das sucessões burocrático, caro e não suficientemente identificado com os ideais liberais. ${ }^{174} \mathrm{O}$ direito das sucessões do $\mathrm{CCBr}$. pode ser, efetivamente, considerado conservador e formal, típico conjunto de normas do século XIX. ${ }^{175}$ Este livro do CCBr. , elaborado em 1899, recebeu influências do direito português, e especialmente do direito francês, havendo ainda uma pequena colaboração do direito italiano. ${ }^{176} \mathrm{~A}$ influência alemã nestas regars do CCBr. foi pequena, apenas os Artigos 1.675, 1.676, 1.677 e $1.679 \mathrm{CCBr}$. teriam sido inspirados em normas do segundo Projeto de BGB, assim como indiretamente os Art. 1.707 und $1.735,1.536 \mathrm{CCBr}$. A influência do primeiro Projeto de BGB restringiu-se aos temas da cláusulas do testamento (Art. 1.675ss. CCBr.), do legado do Art. 1.707 (comparável com o $\$ 1.888$ do Entwurf I), e do fideicomisso no Art. 1.735 (comparável com o $\$ 1.832$ do Entwurf I) e no Art. 1.736 (comparável com o $\$ 1.814$ do Entuurf I). ${ }^{177}$

Projecto Coelho Rodrigues, que se occupam dos contratos na Parte Geral. É bom notar, entretanto, que o legislador allemão, coagido pela força das idéas, volta a considerar os contratos no livro consagrado às relaçōes obrigacionais,...' (Bevilaqua, Em Defeza do Projecto, pg. 128f.)

166. Bevilaqua, Em Defeza do Projecto, pg. 131.

167. Bevilaqua, Em Defeza do Projecto, pg. 141ss.

168. Pontes de Miranda, Fontes, pg. 262.

169. Pontes de Miranda, Fontes, pg. 263.

170. Pontes de Miranda, Fontes, pg. 311 . O autor esclarece que o Art. 1.322 CCBr. inspirou-se no $\$ 609$ do II Vortentwurf de BGB, mas não incluiu a forma "und mußte der Geschättsführer dies erkennen".

171. Pontes de Miranda, Fontes, pg. 211

172. Pontes de Miranda, Fontes, pg. 215s

173. Pontes de Miranda, Fontes, pg. 248 und 250.

174. Pontes de Miranda, Fontes, pg. 340.

175. Veja Pontes de Miranda, Fontes, pg. $342 s$.

176. Bevilaqua, Em Defeza do Projecto, pg. 150ss.

177. Pontes de Miranda, Fontes, pg. 342-345. 
Neste sentido, podemos concluir que a influência material ou de conteúdo do BGB (e do segundo e aprovado Projeto) sobre o CCBr. foi menor nas normas da Parte Especial, do que na Parte Geral. Isto talvez deva-se ao fato que a Parte Geral do BGB alemão ter sido construída com base na doutrina pandectista, momento alto da ciência jurídica alemã ${ }^{178} \mathrm{e}$, portanto, sua aceitação no Brasil, sociedade com características diferentes, foi facilitada pelo seu caráter científico. Cabe, quanto a Parte Especial, repetir o que dissemos anteriormente, frisando a forte influência da doutrina e literatura alemã do século XIX, influência esta superior em muito à influência que pôde ser exercida pelos dois Projetos de BGB e do próprio BGB de 1896.

\section{Conclusão}

Quanto às duas teses aqui analisadas, teses sobre a possível influência do BGB sobre o vigente Código Civil brasileiro, podemos concluir que ambos os Códigos, alemão e brasileiro, apesar da diferença de 20 anos da data de suas aprovações possuem caracteríristicas comuns e podem ser considerados como "produtos" ou criações típicas do século XIX. O momento histórico do liberalismo, o momento político semethante de reafirmação da unidade nacional e o momento científico de desenvolvimento do Direito marcou ambos as codificações e determina sua proximidade até hoje. $\mathrm{O}$ Código Civil brasileiro sofreu múltiplas influências de direitos estrangeiros e, especialmente da Pandectística alemã, mas manteve importante dose de originalidade criativa, graças ao genial Teixeira de Freitas, ao espírito crítico de Coelho Rodrigues e à sabedoria de Clóvis Bevilaqua. A influência germânica nos principais juristas brasileiros do século XIX foi grande, obra da Escola de Recife e de Tobias Barreto, e continua no século $\mathrm{XX}$, com um novo germanismo.

A segunda tese examinada consta da doutrina alemã atual e na doutrina comparatista internacional, segundo a qual a influência alemã no Código Civil brasileiro estaria restrita ao sistema adotado, influência mais sistemática, do que de conteúdo. Em nossa análise podemos identificar que o sistema escolhido pelo legislador brasileiro para o $\mathrm{CCBr}$., com uma parte geral e uma parte especial, possui feições originais e não é simples imitação do sistema alemão. Grande foi a influência - sistemática e no mérito- da doutrina e literatura alemã do século XIX, sendo menor a influência dos dois projetos de $\mathrm{BGB}$ e do $\mathrm{BGB}$ mesmo nas normas adotadas no CCBr.

A tese majoritária hoje na doutrina comparatista não fica aqui confirmada, uma vez que a influência alemã identificada nas normas do $\mathrm{CCBr}$. foi quase tão importante, quanto à influência na distribuição sistemática das matérias. As coincidências sistemáticas de ambos os Códigos podem ser melhor explicadas pela influência comum da doutrina pandectística dominante à época, do que por uma influência direta do BGB no Código Civil brasileiro.
Esta influência doutrinária alemã continua viva em nossos tempos e tende a contribuir nos projetos de atualização do $\mathrm{CCBr}$, como o fez no Código de Defesa do Consumidor ${ }^{179}$, e no próprio Projeto Reale de 1975. ${ }^{180}$ Quanto ao BGB alemão posso afirmar, ao participar destas festividades para a comemoração de seu centenário,como já o fez Ripert sobre o code civil: "A medida que envelhecia, o Código adquiria o prestígio das grandes obras que resistiram ao passar dos anos." $" 181$

Dezembro de 1996.

178. Veja Kohler, pg. 1ss.

179. Veja sobre a influência da Lei alemã sobre condiçóes gerais dos negócios de 1976 (AGBG) sobre a parte contratual do Código de Defesa do Consumidor comentários de Nelson Nery Jr., in: Código Brasileiro de Defesa do Consumidor- Comentado pelos Autores do Anteprojeto, Forense Universitária, Rio de Janeiro, 1991, pg. 270ss. ou meu artigo "Das neue brasilianisch Verbraucherschutzgesetz aus rechtsvergleichender Sicht - Rezeption und Anpassung neuer Rechisideen", in: "La Permeabilite des Ordres Juridiques", Institut Suisse de Droit Comparé, Schulthess, Zurique, 1992, pgs. 111 ss.

180. Veja sobre a influência alemã na Parte Geral do Projeto de Código Civil Brasileiro de 1975, Moreira Alves, A Parte Geral do Projeto de Código Civil Brasileiro, pg. 3ss.

181. Ripert, Georges, El Régimen Democrático y el Derecho Civil Moderno, trad. espanhola, Ed. Cajica Jr, Puebla (México), 1951, pg. 23. 